\title{
Aydın Kuvâ-yı Milliyesi ile Heyet-İ Temsiliye Arasındaki İlişkiler
}

\author{
Doç. Dr. Osman AKANDERE*
}

\section{ÖZET}

Yunanlıların İzmir'i işgalinin bir neticesi olarak ortaya çıkan Aydın Kuvâ-yı Milliyesi, Temmuz 1919 başlarından itibaren bölgedeki otoritesi herkesçe kabul edilen Demirci Mehmet Efe'nin emri altına girmiştir.

Yunan işgalini durdurmaya çalı̧̧an bu kuvvetin, Doğu'daki Mustafa Kemal önderliği'ndeki "ulusalcl" hareketin emrine girmesi Damat Ferit Hükümetlerinin engellemeleri yüzünden erken bir tarihte gerçekleşmemiştir.

Aydın Kuvâ-yı Milliyesi'nin Mustafa Kemal veya Heyet-i Temsiliye ile münasebetleri Ali Rıza Paşa Hükümeti'nin iktidara gelmesiyle birlikte hızlanmıştır. Bunda hükümetin ve hükümet içerisinde Harbiye Nazırı Cemal Paşa'nın özel çabaları etkili olmuştur. İlerleyen zaman içerisinde, Aydın Kuvâ-yı Milliyesi Heyet-i Temsiliye'nin bir icra Kuvveti" olarak yardım yapmıştır. Bu ilişkiler cephenin dağılacă̆ tarihe kadar ahenkli bir şekilde devam etmiştir.

Anahtar Kelimeler: Aydın Kuvâ-yı Milliyesi, Heyet-i Temsiliye, Mustafa Kemal Paşa, Demirci Mehmet Efe, Illişkiler

\section{The Relationship Between the Nationalist Forces of Aydın and The Representative Assembly \\ ABSTRACT}

The Nationalist Forces of Aydin which was appeared due to the occupation of Izmir was entered into Demirci Mehmet Efe's service whose authority in the area was accepted by everybody in early days of July 1919.

Entering into Mustafa Kemel Pasa's nationalistic movement service of the Demirci Mehmet Efe Forces that tried to stop Greek occupation was not able to be possible in an early date because of blockages of Damat Ferit Government.

\footnotetext{
• Selçuk Üniversitesi Eğitim Fakültesi Öğretim Üyesi.
} 
The relationship between the Nationalist Forces of Aydin and Mustafa Kemal or the Representative Assembly was accelerated after Ali Riza Pasa Government took control. The special efforts of the Government and Cemal Pasa who was the Minister of Defence influenced the relationship. The Nationalist Forces of Aydin helped as the Law Execution Force in time. The Relationship continued in order until the dispersion of the front.

Keywords: The Nationalist Forces of Aydin, The Representative Assembly, Mustafa Kemal Pasa. Demirci Mehmet Efe, Relationship.

\section{GİRIŞ}

Demirci Mehmet Efe'nin önderliğindeki Aydın Kuvâ-yı Milliyesi’nin her yönüyle tam bir teşkilatlanma içine girmesi ve bu kuvveti, Damat Ferit Paşa Hükümeti'nin kendi siyaseti doğrultusunda yönlendirme çabaları II.Nazilli Kongresi'(23 Eylül 1919)sonrasına kadar devam etmiştir ${ }^{1}$. Damat Ferit Hükümeti'ni eş zamanlı olarak meşgul eden diğer bir hareket ise, Doğu'da başlayan Mustafa Kemal hareketidir. Her iki hareketin de tam manasıyla teşkilatlanması ve bölgesel bir güç olarak ortaya çıkış tarihleri de yine eş zamanlıdır. Şöyle ki; Mustafa Kemal önderliğindeki ulusalcı hareketin 4-11 Eylül tarihlerinde yapılan Sivas Kongresi'nden sonra nihai kararlarını aldığını, amaçlarını açıkça ortaya koymaya çalıştığını zâhirî de olsa Anadolu'da ortaya çıkan cemiyetleri "Anadolu ve Rumeli Müdâfaa-i Hukuk Cemiyeti” altında birleştirdiğini görüyoruz.

Demirci Mehmet Efe'nin başında bulunduğu Aydın bölgesindeki hareketin ise, II. Nazilli Kongresi'nden sonra, bölgedeki en geniş tabana sahip kongreyi toplamayı başardıklarını ve oluşturdukları Nazilli Heyet-i Merkeziyesi ve buna bağlı olarak oluşturulan Heyet-i Milliyeler vasıtasıyla, bölgedeki örgütlenmelerini tamamladıklarını görüyoruz. Demirci Mehmet Efe'nin bu kongreden sonra "Aydın, Menteşe ve Havalisi Kuvâ-yı Milliye Umum Kumandanı” olması da tesadüfî̀ değildir.

Aydın bölgesindeki bu hareketin kendi içindeki gelişimini tamamlayıp "bir kuvvet" olarak ortaya çıkmasıyla birlikte, İstanbul hükümeti de bu kuvveti kendi siyaseti doğrultusunda yönlendirmeye çalışmıştır. Özellikle Damat Ferit hükümetleri(1919'un yazı) zamanında Aydın Kuvâ-yı Milliyesi üzerinde İstanbul'un belirgin bir etkisi vardır. Nitekim bölgeye Heyet-i Temsiliye tarafından gönderilen Refet Bey daha sonraları mecliste yaptığ bir konuşmasında bu etkiyi şu şekilde dile getirmiștir. "Demirci'nin yanına gittim. O zaman İstanbul'dan Demirci'nin yanına gelen bir zâbit Şarkın kuvvetleriyle( Temsil kuruluna bağll kuvvetler kastediliyor) Demirci'nin

${ }^{1}$ Kongre kararları için bkz. Mustafa Albayrak, Milli Mücadele Döneminde Batı Anadolu Kongreleri, AAM., Ankara 1998.s.,114-117.; Esin Dayı, Nazilli Kongreleri, Atatürk Üniversitesi., Erzurum 1998.,83-103. 
kuvvetlerini zlt bir hale koymak istiyordu. Çünkü o zaman İstanbul, Demirci'ye çalışınız diyordu. ${ }^{2}$ "

Aydın Kuvâ-yı Milliyesi'nin İstanbul'un güdümünden çıkarak Mustafa Kemal hareketi ile yakınlaşmaya başlaması, bu hareketin kendi iç dinamiklerinin etkisi ile başlamış, Damat Ferit hükümeti'nin iktidardan düşmesiyle birlikte iktidara gelen Ali Rıza Paşa hükümetinin uzlaşmacı siyaseti sayesinde giderek gelişme göstermiştir.

Aydın Kuvâ-yı Milliyesi'nin, Heyet-i Temsiliye ile olan münasebetleri şu şekilde bir seyir izlemiştir.

\section{1- Aydın Kuvâ-yı Milliyesi'nin Heyet-i Temsiliye ile Olan İlk Münasebetleri}

Demirci Mehmet Efe'nin, Mustafa Kemal ve başında bulunduğu hareket hakkındaki bilgileri, kendisine yakın olan insanların anlatımına ve basına yansıyan bilgilere dayanır. Demirci Mehmet Efe'ye mücadelenin başından beri yakın olan Albay Şefik Aker, Mustafa Kemal'in 9 Temmuz tarihli askerlikten istifa ettiğini bildiren beyannamesinden itibaren, O'nun mücadelesinden haberdar olduğunu ve Demirci Mehmet Efe'ye Mustafa Kemal'in kahramanlıklarından söz ettiğini söylemektedir ${ }^{3}$. Yine cepheden ayrılmak zorunda kalacağı Eylül 1919 tarihine kadar, Demirci Mehmet Efe'nin yanında bulunan Celâl Bayar da, Damat Ferit Hükûmeti'nin beyanlarının aksine olarak, Mustafa Kemal ve mücadelesinin amacı hakkında Demirci Mehmet Efe'yi aydınlatmaya bilgilendirmeye çalışmışır ${ }^{4}$.

Mustafa Kemal'in hakkında Demirci Mehmet Efe'ye söylenen bu olumlu yöndeki sözlerin Demirci Mehmet Efe üzerinde ne derece tesirli olduğu bilinmez, ancak bilinen bir gerçek varsa o da, Hürriyet ve İtilâfçıların Demirci Mehmet Efe'ye Mustafa Kemal ve mücadelesi hakkında yaptıkları tezviratın ve ifsatların onun üzerinde belli bir süreye kadar daha çok etkili olduğudur ${ }^{5}$.

Şu da bir gerçektir ki, Mustafa Kemal Paşa'yı daha önce tanımayan ve o güne kadar ki ömrünü içtimai hayatın dışında geçirmiş bir insan olan Demirci Mehmet Efe için, bu gibi telkinlere kapılmamak bir hayli zordu ${ }^{6}$.

\footnotetext{
${ }^{2}$ TBMM Gizli Celse Zabıtları, c.2, s.885

${ }^{3}$ M. Şefik Aker, İstiklâl Harbi'nde 57. Tümen ve Aydın Millî Cidali, Askeri Mecmua, c.I., Istanbul 1937,s., 218

${ }^{4}$ Celal Bayar, Ben de Yazdım, C.7, Baha Matbaası, İstanbul 1967,s.,2258-2263.

5 Bunun en güzel kanitı Demirci Mehmet Efe'nin Şefik Aker'e sormuş olduğu şu sorudur. "Mustafa Kemal Paşa İttihatçı imiş, İstanbul Hükûmeti'ni devirmek, İttihatçıları geçirmek için İstanbul'a karşı isyan etmiş" Demirci Mehmet Efe'ye Mustafa Kemal Hareketi'nin sadece ittihatçılık olduğu değil aynı zamanda Bolşeviklik yönün de olduğu telkin edilmiştir. Mustafa Kemal'in düșmanla mücadele ettiği tezini çürütmeye çalışan Hürriyet ve İtilafçılar, Demirci Mehmet Efe'ye "Düşman burada karşımızdadır. Paşa buraya gelsin bizimle çalışsın.."ş̧eklinde telkinlerde bulunmuşlardır. Aker, a.g.e., II.,s.,221

6 Gerçekten o dönemde gerek İtilâf devletleri gerekse Damat Ferit Hükûmeti, "Bolşeviklik" ve "ittihatçılık" senaryolarını, kendilerinin hoşuna gitmeyen hareketleri gözden düşürmek için çok iyi kullanmışlardır. Hatta, değil, Demirci Mehmet Efe, bizzat Sivas
} 
Diğer taraftan Demirci Mehmet Efe'ye çevresindeki insanların bu şekilde telkinlerde bulundukları sirada Mustafa Kemal hareketinin amacı tam olarak netleşmiş değildir ve bu harekete karşı Damat Ferit Hükümeti'nin yürüttüğü amansız bir karalama kampanyası vardır.

Sivas Kongresi'ne Nazilli'yi temsilen delege katılmadığg ve bu kongrenin almış olduğu bir takım kararlara rağmen yaklaşık bir hafta sonra II. Nazilli Kongresi'nin toplandığı düşünülecek olursa, Damat Ferit Hükûmeti'nin bu kampanyalarının bölge üzerinde etkili olduğu kolaylıkla anlaşılır.

Demirci Mehmet Efe'nin, Sivas'taki hareket hakkında Hürriyet ve İtilafçıların telkinlerinden kurtulmasında ve bu hareketle irtibat tesisinde II. Nazilli Kongresi'ne katılan Muğla delegasyonu etkili olmuştur? ${ }^{7}$. Daha önce yapılan I. Nazilli Kongresi'ne katılamayan ve Demirci Mehmet Efe'nin tehditleri sonucunda, Nazilli'ye bir delegasyon göndererek, kongre hakkında bilgi alan Muğlalılar, bundan sonra 18 Ağustos tarihinde başta Mutasarrıf Hilmi Bey olmak üzere, Belediye Başkanı Rağıp Bey ve Ulalı Hamza Bey’in önderliğinde bir kongre düzenlemiştir ${ }^{8}$.

$\mathrm{Bu}$ kongreden sonra, II. Nazilli Kongresi öncesine kadar, başta Mutasarrıf Hilmi Bey olmak üzere, Muğla Kuvâ-yı Milliyesi'nin önde gelenleri, bir durum değerlendirmesi yapmıştır. Hilmi Bey, II. Nazilli Kongresi'ne hareket etmeden bir gün önce 17 Eylül'de toplamış olduğu kongre sonrasında İstanbul Hükûmeti ile ilişkileri keserek, Sivas'a bağlanma kararı almıștır. Mutasarrıf Hilmi Bey, o güne kadar cephe ile olan ilişkilerindeki, açığı kapatmak istercesine II. Nazilli Kongresi'ne kalabalık bir delege topluluğunun yanında, 530 kişiden oluşan bir milis grubuyla katılmıştır?.

Muğla delegasyonu, Nazilli Kongresi'ne birçok teklifte bulunurlar ve bu teklifler arasında Doğu'daki Mustafa Kemal Hareketi ile yakınlaşma isteği de vardır. Ancak Muğla temsilcilerinin bu isteği, kongre başkanı Nuri Bey'in sürekli karşı gelmeleri ve Doğu'daki hareketin henüz yeterince bilinmediği gerekçesiyle geçiştirilmiştiir ${ }^{10}$.

Mutasarrıf Hilmi Bey, kongreye gitmeden önce almış olduğu kararı II. Nazilli Kongresi'nde bir karara dönüştürmeyi başaramasa bile, Demirci Mehmet Efe'yi kısa zamanda etkilemeyi başarabilmiştir. Hilmi Bey, bu ziyaret sırasında bölgenin kumandanlığını Demirci Mehmet Efe'ye tevdi etmiş olacak ki, Demirci Mehmet Efe, 11 Ekim'de "Görülen lüzûm üzerine Menteşe Sancă̆ı Kuvâ-yı Milliye Kumandanlı̆̆ını da deruhte eylediğini”

Kongresi'nde Mustafa Kemal'in çok yakınında bulunan insanlar bile, peşinden gittikleri hareketin "ittihatçılık" yönünden kuskulanmıs ve bu kuşku Sivas Kongresi'nin yemin metnine yansımıștır. Türk İstiklâl Harbi, c.II.,Kısım İ, Genelkurmay Basımevi, Ankara 1999,s.,15.

7 Ünal Türkeş, Kurtuluş Savaşı'nda Muğla, İstanbul 1973,s, 333.

${ }^{8}$ A.g.e. s, 318 .

${ }^{9}$ A.g.e. s.328,329; Dayı, a.g.e. s, 86 .

${ }^{10}$ Türkeş, a.g.e., s.,330. 
ilan etmiştir ve bundan sonra bölge ile ilgili her türlü müracaâtın kendisine yapılmasını istemiştir ${ }^{11}$.

Mutasarrıf Hilmi Bey'in Demirci Mehmet Efe'nin karargahındaki faaliyetlerini, Muğla Belediye Başkanı Ragıp Bey'in, Nazilli'den göndermiş olduğu şu telgrafından öğreniyoruz: "Mutasarrıf Hilmi Bey, Demirci Mehmet Efe'nin pek ziyade teveccühünü kazandı. Efe, kendisini daima yanından ayırmak istemiyor. Muğla'da olduğu gibi burada da Sivas harekâtını Bolşeviklik ve İttihatçılıkla itham ederek Efe üzerinde teşvikâtta bulunmağa çalışan Hürriyet ve İtilâfçıların ifsâdâtından ve Nazilli Heyeti'nin hâlâ devam eden inadına răgmen Efe'yi umum harekât ideâline tevcih ve temayül ettirmeğe muvaffak oldu. Bu hususta Efe nezdinde Hilmi Bey kadar teveccühe mahzar olan Antalya Murahhası Nuri Bey'le işbirliği yapmıştır. Yakında kovalanan gayeye ulaşılacaktır.... ${ }^{12}$,

Ragıp Bey'in "kovalanan gayesine", fiilen olmasa da resmi olarak ulaşıldığını, Demirci Mehmet Efe'nin emrinde "Harekât-1 Harbiye Reisi" olan Tâhir Bey' in, 7 Ekim tarihinde, Sivas'a cephenin durumunu bildiren bir harp raporu göndermesinden anlıyoruz ${ }^{13}$. Tâhir Bey' in cephe ile ilgili raporunu okuyan Heyet-i Millîye Riyaseti, "kahraman mücahitlere selâm ve ihtiramlarını" gönderdi ${ }^{14}$. Demirci Mehmet Efe'nin kumandası altındaki Aydın cephesi ile Heyet-i Temsiliye arasındaki en erken tarihli yazışma bu olsa gerekir.

Görüldüğü gibi Heyet-i Temsiliye ile Demirci Mehmet Efe arasındaki irtibat, Damat Ferit Hükûmeti'nin düşürülmesinden hemen sonra, Ekim ayının ilk haftasından itibaren başlamıştır.

Aydın Cephesi ile Heyet-i Temsiliye ilişkileri açısından çok önemli bir adım sayılabilecek diğer bir gelişme ise, doğrudan "Demirci Mehmet Efe'den Heyet-i Temsiliye Riyâsetine" hitâbıyla, Mustafa Kemal'e gönderilen telgrafnamedir ${ }^{15}$.

Demirci Mehmet Efe, telgrafına “Milletin tasvip ve teşebbüsü ile, Cenab-ı Hakkın muâvenetine istinâden, Yunanlılara karşı bir hayli zaman evvel cihat ilan ettiğini" belirterek başlar. Demirci Mehmet Efe, Mustafa Kemal' i kastederek "Zat-ı âlileri gibi umum milletin itimadına mazhar olan muhterem bir kumandanımızın istihlası vatan uğrunda, ifna-yi hayat etmek üzere, meydan-ı cihada atılmış olması, maneviyatımızı fevkalâde takviye eyledi" dedikten sonra; Yunanlıların İngilizlerin "müsâade ve müsâmahası" ile her tarafta tedarikte bulunduklarını ve kuvvetlerini bütün manasıyla tezyit

"I TiTE Arş, KN: 91; GN:24; BN: 24/18

${ }^{12}$ Türkeş, a.g.e., s., 333; Demirci Mehmet Efe'nin "İttihatçılık "konusunda uyarıldığı konusundaki anlatımlar için bkz. Hacim Muhittin Carıklı, Balıkesir ve Alaşehir Kongreleri ve Hacim Muhittin Çarıklı'nın Kuvayı Millîye Hatıraları(1919-1920), yay. Haz. Şerafettin Turan, Ankara 1967, s.51-53.

${ }^{13}$ TiTE Arș, KN: 91; GN:23; BN: 23/14.

${ }_{15}^{14}$ Bekir Sıtkı Baykal, Heyet-i Temsiliye Kararları, TTK., Ankara 1974.s.,14

${ }^{15}$ ATESE, Arş.,KI: 329,D:91, Fh: 38 
ettiklerini, süratle noksanlarını ikmal ettiklerini, Aydın-Ödemiş- Manisa cephelerinde otuz beş bin tahmin edilen Yunanlıların, pek yakın zamanda umûmi harekâta başlayacaklarını haber verir. "Efelerin bașında bulunan zâbıtanın himmet ve gayretlerinin şayan-l takdir olduğunu" söyleyen Demirci Mehmet Efe, "o günden beri" bazı yerlerde devam eden muharebelerin Yunanlıların bomba ve büyük çaplı toplarla vuku bulan saldırılarına sebep olduğunu da belirtir.

Demirci Mehmet Efe'nin "o günden beri" demesinden, bu tarihten önce cephe hakkında malûmât verildiği anlaşılmaktadır. Demirci Mehmet Efe'nin sözünü ettiği günün, Tâhir Bey'in göndermiş olduğu harp raporu olma ihtimali vardır.

Demirci Mehmet Efe'nin bu telgrafında, kış mevsiminin yaklaştığını hatırlattıktan sonra "dâr-l diyar olan ve erkekleri Yunanlılar tarafindan katledilmesinden dolayı köylerde ve dağlarda gayet sefil ve perişan bir halde imrar-l evkat(vakit geçirmek) etmekte olan 150 bin nisvan(kadin) ve sıbyan(çocuk)"ın durumlarına dikkat çektiğini ve çocukların hayatlarının kurtarılması ve bunların biran evvel vatanlarına îâde edilmesi için bir hafta sonra milli kuvvetler tarafından harekete geçmeye karar verdiklerini Mustafa Kemal'e ilettiğini görüyoruz.

"Maksat ve gayemiz, mukaddes vatanımızdan alçak Yunanlılart çıkarmak ve pek feci surette öldürülen İslâm kardeşlerimizin intikamını almaktan ibarettir" diyen Umum Kumandan Demirci Mehmet Efe, "bu hususta fedakâr ordumuzun bizlere muayyen ve müzahir olacaklarından emin olduklarını" sözlerine ilave ettikten sonra, cephaneye şiddetle ihtiyaçların olduğunu ve bu konuda Konya Kolordu Kumandanlığı'na ve sair icap edenlere emir verilmesini ister.

Demirci Mehmet Efe, Mustafa Kemal'e gönderdiği bu ilk telgrafını şu sözlerle tamamlar: “...Bu havalinin de tamamı ile, meşruiyetine kanaât getirilen Sivas Kongresi mukarrerâtına iştirak ettiğini, arz ve beyan ve hangi cihetlerden ne suretle ne vakte kadar muâvenet olunacă̆ı bilinmek üzere, süratle malûmât buyurulmasını istirham ve bu vesile ile takdimi ihtiramat eylerim."

15 Ekim tarihli bu telgrafından da anlaşılacağı üzere, Aydın ve Menteşe ve Havalisi Kuvâ-yı Milliye Kumandanı olan Demirci Mehmet Efe, daha bu tarihlerde Sivas Kongresi kararlarını kabul etmiş ve Mustafa Kemal ile resmen irtibata geçmek istemiştir ${ }^{16}$. Demirci Mehmet Efe'nin daha ilk andan

${ }^{16}$ Demirci Mehmet Efe'nin 15 Ekim tarihli bu telgrafında Sivas Kongresi'nin kararlarına iştirak ettikleri yönündeki beyanatı, 6 Aralık tarihinde göndermiş olduğu bir başka telgrafında "Sivas Kongresi mukarreratının bizlerce kabîl-i tatbik ve icra olan aksamı Nazilli Kongresi'nce kabul edilmiştir" şeklindedir. (H.T.V.D.sayı: 114. Belge No: 4233) Demirci Mehmet Efe'nin bu ifadelerinden Sivas Kongresi kararlarının kabul edilip edilmeyeceği konusunda II.Nazilli Kongresi'nde bir karara varıldığı anlaşılmaktadır. Nitekim daha öncede belirttiğimiz gibi II. Nazilli Kongresi'ne katılan Muğla delegasyonu bu konuyu gündeme 
itibaren, Mustafa Kemal'i bir fevki gibi görmeye başladığı ve ona göre beyanlarda bulunduğunu kullandığı üslûptan anlıyoruz. Ayrıca, Demirci Mehmet Efe'nin imzasını taşıyan bu ve benzeri telgraflardaki ifadelerin bölge insanının düşüncelerini yansıttığı hatırdan çıkarılmamalıdır.

\section{2- Demirci Mehmet Efe'nin Aydın't Umumi Bir Taarruzla Alma Fikri}

Demirci Mehmet Efe'nin başında bulunduğu, Aydın Kuvâ-yı Milliyesi'nin 1919 Ekim ayının ilk günlerinden itibaren, Yunan kuvvetlerine karşı saldırı hazırlıkları içerisinde olduğunu, Demirci Mehmet Efe'nin Köşk'ten 4 Ekim tarihinde göndermiş olduğu bir telgraftan anlıyoruz ${ }^{17}$. Demirci Mehmet Efe bu telgrafında, "Tahkik heyetlerinin tebliğ ve tavsiye ettikleri tevakkuf müddeti bu akşam hitam bulduktan sonra yarından itibaren Kuvâ-yı Milliye'nin düşmanı ezmek için firsat kollayacağını" duyuruyor; millî ordunun başarılı olabilmesi için, beş vakit namazdan sonra Cenab-1 Hak'a dua edilmesini ve fetih sûresinin okunmasını istiyordu.

Nazilli Heyet-i Merkeziyesi'nin almış olduğu bu kararı Heyet-i Temsiliye Riyaseti'ne bildiren ve cephane talebinde bulunan Demirci Mehmet Efe, aynı kararı, Harbiye Nâzırı Cemâl Paşa'ya da bildirmiştir. Aynı gün, Cemâl Paşa, Demirci Mehmet Efe'ye göndermiş olduğu cevapta şunları belirtir: "Bu güne kadar Kuvâ-yı Milliye'nin başlarında müdür efeleri olduğu halde gösterdikleri kahramanlı̆̆ kaydedecektir. Hep bu kuvvetlerin gösterdikleri fedakârlıktır ki, Izmir ve Aydın mintıkasına bir tahkik heyeti göndermeye saik olmuştur. Bu heyetin netice-i tahkikatı Yunan fecâ̂̉ bütün açıklığı ile meydana çıkmıştır. Heyet bu gün raporunu ikmal ederek Paris'e gönderdi vakanın pek lehimize olarak cereyân ettiği şu sırada tarafımızdan bir taarruza kalkmak heyetin lehimize yazdı ̆̆ rapor üzerine Paris'te aksi tesir yapabilir ve işte "Türkler heyetin tahkikatını beklemeden tecavüze başladılar diye bize haksızlık atfederler; binâenaleyh bu raporun Paris'te yapacağ t tesirin neticesine intizaren beklemek hakkımızda hayırlısı olacaktır. Bu raporun neticesinden bir hüsnü netice çıkmaz veyahut daha evvel Yunanlılar tecavüze başlarsa o vakit millet hep birlikte işe başlar. Raporun neticesinden evvel Yunanlıların bir taarruza başlayacaklarını zannetmiyorum. Binâenaleyh, raporun Paris'te vereceği neticeden evvel bir taarruza başlanmamasını tekrar ricâ ederek Cenab-l Hakkın cümlenize muin olmasını temenni eylerim. Yunanlıların yerlerinden kımıldamamaları için burada teşebbüste bulunuldu ve katiyen

getirmiş, Mustafa Kemal hareketi ile olan münasebetler konusunda tartışma ortamı yaratmıştır.

Esin Dayı, Demirci Mehmet Efe'nin bu telgraftan yola çıkarak, Nazilli Heyet-i Merkeziyesi'nin Sivas Kongresi kararlarını kabul etme tarihini 3 Aralık tarihi olarak vermektedir. (a.g.e., 175.) Halbuki, bu tarihten çok önceleri bu konu II.Nazilli Kongresi'nde gündeme getirilmiş, Sivas ile irtibata geçilmeye karar verilmiştir. Bundan sonra Demirci Mehmet Efe ile Heyet-i Temsiliye arasında önce yazışma şeklinde sonra ise bir heyet göndermeye kadar varacak ilişkiler başlamıştır. Nitekim Demirci Mehmet Efe, daha 15 Ekim tarihli telgrafında Sivas Kongresi kararlarına katıldıklarını ifade etmektedir.

${ }^{17}$ TITE Arş, KN: 72; GN:6; BN: 6: 
bir hareket yapmamalarının kendilerine emredildiği İngiliz mümessillerine bildirildi ${ }^{18}$."

Görüldüğü gibi Cemâl Paşa, Aydın'ın yapılacak genel bir taarruzla alınmaya çalışılmasının mahzurlarını makul bir dille Demirci Mehmet Efe'ye anlatmıştır.

Cemâl Paşa, aynı gün istifasını isteyen 57. Fırka Kumandanı Şefik Aker'e göndermiş olduğu telgrafında, Aydın'a taarruz kararı ile ilgili olarak "Aydın'a taarruz yapılmaması hususunun teminini son derece ricâ ederim. Çünkü bunun maddeten imkanı olmadığı gibi şu sırada siyaseten katiyen câiz değildir" demiştir ${ }^{19}$.

Cemâl Paşa, bu yazışmalardan sonra Aydın Cephesi ile ilgili Heyet-i Temsiliye'ye bir takım mütâlaalarda bulunmuş olacak ki, Heyet-i Temsiliye'nin aynı gün ki kararlarında "Vâki olan istifsar (soru) üzerine, Harbiye Nazırı Cemâl Paşa'nın, Aydın cephesi hakkında alınan mütalaalarının Ali Fuat Paşa'ya ve Miralay Refet Bey'e işarına karar verildi $^{20 "}$ " denmektedir. Yine bu tarihten sonra Cemâl Paşa, Aydın Kuvâ-yı Milliyesi'nin her türlü ihtiyaçlarını Konya'da bulunan 12. Kolordu aracılığıyla temin etmeye karar vermiş olmalıdır ki, 18 Ekim'den itibaren bölgede bulunan 57.Fırka'nın, Konya'da bulunan 12. Kolordu'ya bağlandığını Fırka Kumandanı Şefik Aker'e bildirmiştir ${ }^{21}$.

\section{Demirci Mehmet Efe'nin Sivas'a Gönderdiği Murahhas Heyeti:}

Demirci Mehmet Efe'nin, Heyet-i Temsili'ye ile irtibata geçmek istediği, Mustafa Kemal Paşa'ya göndermiş olduğu 15 Ekim tarihli telgrafından anlaşılmaktadır.

Demirci Mehmet Efe'nin bu telgrafına Mustafa Kemal Paşa'nın cevap verip vermediği konusunda bir bilgimiz yoktur. Ancak Mustafa Kemal Paşa'nın 16 Ekim'de Amasya Mülâkatı için Sivas'tan ayrıldı̆̆ı ve Cemâl Paşa'nın da 15 Ekim'de Aydın cephesi ile ilgili olarak Heyet-i Temsiliye'ye mütalaada bulunduğu göz önüne alınırsa, Mustafa Kemal Paşa'nın Aydın cephesi ile ilgili gelişmelerden Amasya'ya gitmeden önce haberdar olduğu anlaşılır.

Bu yazı̧̧madan sonra, Demirci Mehmet Efe'nin, 27 Ekim tarihinde, Hoca Süleyman Efendi başkanlığında, Muğla Mutasarrıfı Hilmi Bey, Çerkes Yusuf Bey, Kâzım Nuri Bey’den mürekkep bir heyeti Sivas'a gönderdiğini görüyoruz $^{22}$. Demirci Mehmet Efe'nin Mustafa Kemal Paşa'ya hediye olarak

\footnotetext{
${ }^{18}$ Aker, a.g.e., III.s., 6

${ }^{19}$ a.g.e., III.,s.,5.

${ }^{20}$ Baykal, a.g.e., s. 22.

${ }^{21}$ Aker, a.g.e., III.s., 8 .

${ }^{22}$ Demirci Mehmet Efe'nin göndermiş olduğu bu heyetteki Çerkes Yusuf Bey'i Asaf Gökbel, Milli Müicadele'de Aydın, Coskun Matbaası, Aydın 1964,s, 392'de, Denizli Heyet-i Milliye Üyesi olan Başağa zade Yusuf Bey'le karıştırmıştır. Aynı hataya Gökbel'i kaynak gösteren Esin Dayı'da düşmüştür. Oysa Başağa zade Yusuf Bey, bu heyette değil, Denizli'den
} 
gönderdiği silahı da yanlarına alan heyet üyeleri ${ }^{23}$, Nazilli'den hareketle, Dinar-Afyon- Ulukışla-Niğde- Kayseri güzergâhını takiben 13 Kasım 1919 'da Sivas'a varmıştır ${ }^{24}$. Heyet üyelerinden Mutasarrıf Hilmi Bey, 29 Ekim'de Karahisar'da (Afyon) Tasvir-i Efkar Muhabiri Arif Oruç'a heyetin Sivas'a gidiş amacı ile ilgili olarak, Nazilli ve civarındaki Kuvâ-yı Milliye'nin, Heyet-i Temsili'ye ile münasebet temin etmek istediğini, vâki olan davet üzerine bir "heyet-i murahhasa" nın Sivas'a giderek, aynı gayede olan hareketlerin teferruatında dahi birlik temini maksadında olduğunu ifade etmiștir ${ }^{25}$. Heyet üyeleri Tasvir-i Efkar'ın dıșında Ögüt gazetesi muhabirlerinden birisiyle de bir mülâkat gerçekleştirmişler ve kendilerine sorulan çok önemli soruları cevaplandırmışlardır ${ }^{26}$. Ögüut muhabiri de heyet üyelerine öncelikle amaçlarını sormuş, heyet adına bu soruya cevap veren Hilmi Bey, harekât-1 milliyenin merkezinin Sivas olduğunu hatırlattıktan sonra, "Aydın vilâyeti havalisinin hususi halleri hakkında lâzım gelen malûmâtı vermek ve oradan tâlimat almak için gittiklerini" ifade etmiştir ${ }^{27}$.

Heyet üyeleri 13 Kasım'da Sivas'a varmıştıิ ${ }^{28}$. Hilmi Bey'inde ifade ettiği gibi, heyet üyeleri Sivas'ta bulundukları zaman zarfında Aydın havalisinin hususi halleri hakkında gerekli malûmâtları verdikten ve bölgeyle ilgili Heyet-i Temsiliye'nin talimatlarını aldıktan sonra tekrar aynı güzergâhı takip ederek 13 Aralık'ta Nazilli'ye dönmüştür ${ }^{29}$. Heyet üyelerinden yalnızca Menteşe Mutasarrıfı Hilmi Bey dönmemiştir.

Sivas Kongresi'ne giden delegeler arasındadır. Çerkes Yusuf Bey, Nazilli'nin önde gelen eşraflarından olan ve Demirci Mehmet Efe'nin itimadını kazanan birisidir. Celâl Bayar, Kâzım Nuri Bey'in Heyetten ayrılarak bilinmeyen bir sebepten dolayı İstanbul'a gittiğini söylemektedir. Bayar, a.g.e., c.7.,s.146. Bayar'ın bu verdiği bilginin doğruluğu, Arif Oruç'un 29 Ekim tarihinde Afyon'dan göndermiş olduğu mektupta Kâzım Nuri Bey'den söz etmesinden anlaşılıyor. Yücel Özkaya, Milli Mücadele'de Ege ve Çevresi, Kültür Bakanlığı yay., Ankara 1994,s.,95; Nitekim Heyet-i Temsiliye'nin 21 Kasım tarihli kararlarında Demirci Mehmet Efe'nin gönderdiği heyet üyelerinden bahsedilirken Kâzım Nuri Bey'den bahsedilmez. Baykal, a.g.e., s, 62

${ }^{23}$ Kemal Ariburnu, Sivas Kongresi, AAM., Ankara 1997.s., 232.

${ }^{24}$ Gökbel, a.g.e. s., 393; Day1, a.g.e. s., 169.

${ }^{25}$ Özkaya, a.g.e. s.,95

${ }^{26}$ Öğüt gazetesi'nin bu mülakatı 11 Kasım 1919 tarihli Vakit Gazetesi’nde çıkmıştır.

${ }^{27}$ Ögüt muhabirinin sormuş olduğu diğer sorular ve almış olduğu cevaplar ise şöyledir: Aydın ve havalisi ne haldedir?

Bütün cihanın malumu olduğu veçhile İzmir'in işgalini takip eden Yunan fecayi, Aydın ve havalisini işgal ile tekrar etti. Insanlığın kabul edemeyeceği mezalim ve fecayi vakaya karşı Aydın vilâyeti ahalisi meşru haklarını Müdâfaa için mukabeleye ve adalet ile iş gördüklerini iddia eden itilâf devletlerinin adil-i hayatlarına müracaâta mecbur kaldı. Vaki olan mukabele hareketlerinizle ne kazanabildiniz?

Meşruu hakkını Müdâfaaya azim için her millet gibi bizde naçar silaha sarıldık. Ve mezalimin yapılmasına ve devam etmesine mani olduk. Bu yaptığımızın büyük devletlerce meşruu telakki edildiğini zannediyoruz. Emin olunuz ki bu zulümleri ortadan kaldırınca yani sevgili İzmir'i kurtarıncaya kadar bu suretle müdâfaada sebat ve devam etmekte azim eyledik. Vakit, 11 Kasım 1919.

${ }^{28}$ Gökbel, a.g.e. s., 393. Day1, a.g.e. s, 169

29 Mustafa Kemal Paşa' Demirci Mehmet Efe'nin kendisine göndermiş olduğu hediyesine karşılık olarak, Heyet'e Demirci Mehmet Efe'ye verilmek üzere, bir silah, bir dürbün, bir de eğer göndermiş, Mustafa Kemal Paşa'nın hediyesini alan Demirci Mehmet Efe' Çerkez Yusuf Bey'e “ İnce Adam, derin adam, zeki adam bu!" demiş ve aldığı basit hediyeleri kendi açısından, şu şekilde anlamlandırmıştır: "Bin, gör ve vur demektir bu! hiç 


\section{4- Demirci Mehmet Efe'nin Heyet-i Temsiliye Tarafindan Uyarılması}

Heyet-i Temsiliye Riyâseti, 25 Kasım'da Demirci Mehmet Efe'den "düssmanların propagandalarına meydan vermemek için hiçbir ecnebi zâbitinin cephede kitaât ile temasına katiyen meydan verilmemesini ve resmi müracaatlarının hükûmete ĕger Kuvâ-yt Milliye'ye ait ise geri Heyet-i Merkeziyelere ve bunlar delâletiyle Heyet-i Temsiliye'ye yapılmasını" ayrıca "propaganda yapan ecnebi zâbitlerinin tahte'l hifz(muhafaza altında) mintıkadan ihrâcını ve mecburiyet-i katiye hâsıl olursa Ingiliz ve Fransızlara da cephede silah istimâl edilmesini" istemiști ${ }^{30}$.

Demirci Mehmet Efe, Sivas'tan aldığı bu talimattan sonra Aydın'ın Yunanlılar tarafından boşaltılarak, yerine Fransız ve İngiliz askerlerinin yerleştirilmesi konularının tartışıldığı günlerde, bölgeye gelen İngiliz Albayı İmling ile görüşmüştür ${ }^{31}$. Demirci Mehmet Efe, İngiliz Albayı İmling ile arasında geçen görüşme hakkında Mustafa Kemal Paşa'ya 3 Aralık'ta gönderdiği bir telgrafname ile bilgi vermiştir ${ }^{32}$. Demirci Mehmet Efe, İngiliz Albayı'na, İzmir ve Aydın vilâyetinde bir tek Yunan askeri kalmayıncaya kadar mücadeleye karar verdiklerini, Yunanlılarla olan temaslarını engellemek için araya İngiliz ve Fransız kuvveti yerleștirilse bile silah kullanmaktan çekinmeyeceklerini ifade etmiştir. Demirci Mehmet Efe'nin bu sözlerinden duyduğu memnuniyetsizliği Hareket-i Harbiye Reisi vasitasıyla Demirci Mehmet Efe'ye ileten İngiliz Albayı İmling, "İngiliz ve Fransızlara karşı silah istimâl edilece ği tabirinden müteessir olduğunu, Ingilizlere karşı daima mülâyim lisanın hakkımızda hayırlı olacă̆ını" söylemiştir. Demirci Mehmet Efe, buna karşılık olarak "karşılarına her kim çıkarsa çıksın vatanı istihlâs etmek için bundan başka sözlerinin olmadığını ve bundan sonra da olmayacağını" ifade etmiştir.

Mustafa Kemal, Heyet-i Temsiliye namına 7 Aralıkta vermiş olduğu cevabında: "Ingiliz Miralayına evvelce vaki olan beyanat-ı âlileri ve bilâhare gönderilen cevap son derece şayanı iftihardır. Vatanı tahlis(kurtarma) için fedâ-yı hayatı göze almış Zât-ı âlileri gibi dindar, hamiyetkâr bir cephe kumandanının ifâdât-ı kat'iyesi Milletin azm-i kararını düşmanlarımıza en güzel ispat eder" dedikten sonra bu zamana kadar Aydın cephesinde yapilan mukavemetin siyasi vaziyetimize "pek iyi tesir" yaptığını, bundan sonra da "ufak tefek baskınlarla düşmanı iz'aç eylemenin" maksada en uygun hareket tarzı olacağını ifade etmiştir ${ }^{33}$.

Görüldüğü gibi Demirci Mehmet Efe, 25 Kasım tarihli tâlimata uygun bir davranış sergilemiş ve bu nedenle Mustafa Kemal Paşa tarafından taltif

ağzını açmadan , bir kitaplık emir vermiş bana koca adam. Ben kumandan diye işte böylesine derim” demiştir. Naci Sadullah Daniş, "Oğlu Demirci Mehmet Efe'yi Anlatıyor.", Demokrat İzmir Gazetesi, Tefrika No: 37

${ }^{30}$ Baykal, a.g.e. s.,63,64

${ }^{31}$ Şefik Aker, İmling'ten ordu papazı olan, 50 yaşlarında tatlı, güler yüzlü biri olarak bahseder. Aker, a.g.e. s.III.s.,89

${ }_{33}^{32}$ Atatürk'ün Millî Dış Politikası, I. K.B., Ankara 1992,s.,112.

${ }^{33}$ A.g.e. s., 114 . 
edilmiştir. Refet Bey'in bölgeye gönderilmesine rağmen Mustafa Kemal Paşa'nın Demirci Mehmet Efe'ye "cephe kumandanı" olarak hitap etmesi dikkatten kaçmamalıdır.

\section{5- Refet Bey'in Demirci Mehmet Efe'den Kumandayı Almak Amacıyla Bölgeye Gönderilmesi}

Heyet-i Temsiliye'nin Batı Cephesi'ndeki Kuvâ-yı Milliye faaliyetlerine düzen verme çabaları, Sivas Kongresi'nin devam ettiği sıralarda, bölgeye, Ali Fuat Paşa'yı "Garbi Anadolu Umum Kuvâ-yı Milliye Kumandanı" olarak atamasıyla başlamıştı ${ }^{34}$. Ali Fuat Paşa, bu göreve atandıktan sonra, Kuvâ-yı Milliye'yi geliştirme çalışmalarına hızla devam etmiştir. Ali Fuat Paşa, bu yöndeki çalışmalarını daha çok Bilecik, Eskişehir ve Bursa bölgelerinde yoğunlaştırmış, Demirci Mehmet Efe'nin hâkimiyeti altında bulunan, Aydın bölgesi ile pek fazla ilgilenememiştir. Bölge ile kendisinin ilgilenemeyeceğini anlayan Ali Fuat Paşa, 14 Eylül 1919'da Heyet-i Temsiliye'ye çektiği telgrafında "Aydın Kuvâ-yl Milliyesi'ne muktedir bir kumandan bulamıyorum. Bu vazifeyi burada îfâ edebilecek fazla bir kimsemiz yoktur. Evvel ve âhir istirham eylediğim veçhile Refet Bey Efendi'nin bu havaliye gönderilmesini ricâ ederim" teklifinde bulunmuştur ${ }^{35}$.

Ali Fuat Paşa'nın bu teklifine, Heyet-i Temsiliye'nin başında bulunan Mustafa Kemal Paşa'nın ne tür bir cevap verdiği konusunda her hangi bir bilgimiz yoktur. Ancak, o sıralarda Heyet-i Temsiliye'nin Sivas Kongresi ve sonrasında Damat Ferit Hükûmeti ile ilişkilerini kesmesi vb. olayları göz önüne alarak Heyet-i Temsiliye'nin, Ali Fuat Paşa'nın Aydın Kuvâ-yı Milliyesi'nin başına "muktedir bir kumandan" göndermeye meselesini ileriki bir tarihe ertelemek zorunda kaldığını söyleyebiliriz.

Heyet-i Temsiliye'nin, Aydın Kuvâ-yı Milliyesi'ne olan ilgisi, 2 Ekim'de göreve gelen Ali Rıza Paşa hükûmeti zamanında yeniden başlamıștır. Özellikle yeni kabinede bulunan Harbiye Nazırı Cemâl Paşa'nın Kuvâ-yı Milliye'ye olan yakınlığı ve Anadolu'da başlayan bu harekete sempati ile yaklaşması, bu hususta etkili olmuştur. Nitekim, Mustafa Kemal Paşa, Cemâl Paşa'ya göndermiş olduğu kutlama telgrafında kendilerinin başarılı olmaları için ellerinden geleni yapacaklarını, bütün ordu ve Kuvâ-yı Milliye'nin kendilerine yardımcı olacaklarını beyan etmiş ve Cemâl Paşa'dan birtakım isteklerde bulunmuştur. ${ }^{36}$. Mustafa Kemal Paşa'nın bu istekleri arasında Refet Bey'in Konya'daki 12. Kolorduya atanmasi teklifi de vardır.

Mustafa Kemal Paşa, 12 Ekim 1919 tarihli, Cemâl Paşa'ya göndermiş olduğu telgrafında, Aydın cephesi ile ilgilendiklerini bildirerek; bu cepheyi düzene sokmak için Refet Bey'in resmi olmadan görevlendirilmesini

${ }^{34}$ Sina Akşin, İstanbul Hükûmetleri ve Millî Mücadele, Türkiye İş Bankası yay.,II, İstanbul 1983.s., 75 .

${ }^{35}$ Ali Fuat Cebesoy, Millî Mücadele Hatıraları, Temel yay, İstanbul 2000, s.230,231.

${ }^{36}$ Mustafa Kemal Atatürk, Nutuk, A.A.M. Ankara 2002, s., 171. 
istemişti $^{37}$. Mustafa Kemal Paşa'nın bu telgrafını göndermesinden üç gün sonra, Demirci Mehmet Efe'nin Aydın'a taarruz fikrini Cemâl Paşa'ya ve Mustafa Kemal Paşa'ya bildiren haberleşmeleri gerçekleşmiştir. Özellikle, Demirci Mehmet Efe'nin bu telgrafını ve bölgedeki hükûmetin en yüksek rütbedeki kumandanı olan Albay Şefik Aker'in istifası ile ilgili telgraflarını alan Cemâl Paşa, Mustafa Kemal'in 12 Ekim tarihli teklifine hız vermek istemiş olacak ki, 15 Ekim'de Heyet-i Temsiliye' den Aydın cephesi ile ilgili bir takım mütalaalarının Ali Fuat ve Refet Paşa'ya iletilmesini istemiştir ${ }^{38}$.

Aydın Kuvâ-yı Milliyesi'nin durumu, Mustafa Kemal Paşa ile Salih Paşa arasında gerçekleştirilen Amasya Mülâkatı'na da yansımıştır. Salih Paşa'nın altına imza koyduğu dördüncü protokolün sekizinci maddesinde “ Aydın Kuvâ-yı Milliyesi'nin güçlendirilmesi ve beslenmelerinin kolaylıkla sağlanması"na karar veriliyor; bu hususta, Donanma Cemiyeti'nin 400.000 lirasından gerektiği kadarının, hükûmet tarafından bu maksat için ayrılmasına karar veriliyordu ${ }^{39}$.

Nihayet 23 Ekim 1919'da Heyet-i Temsiliye, aldığ Bey'i Aydın Cephesi Kuvâ-yı Milliye Kumandanlığı'na getirdi' ${ }^{40}$. Mustafa Kemal, Refet Bey' in bu göreve getirilişi ile ilgili olarak Nutuk'ta şunları söylemektedir. "Salihli ve Aydın cephelerindeki sevk ve idarenin askeri bir düzene sokulması gerekiyordu. Buraya az çok tanınmış bir askerin gitmesi lâzımdı. Elimizde yararlanabileceğimiz komutan olarak Konya'da bulunan Refet Paşa vardl. Konya'daki kolordunun başına Fahrettin Bey geçmiş bulunuyordu. Bundan dolayı, Aydın Kuvâ-yı Milliye Komutanlı̆̆ı'nı yürütmek üzere cepheye hareketini Refet Paşa'ya, Ankara'ya dönmesini de Ali Fuat Paşa'nin kendisine yazmıştık ${ }^{41}$."

"Nazilli Mevki Kumandanı Servet Bey" örtülü ismini alan Refet Bey, Yunan ilerleyişine karşı Salihli ve Aydın'da askeri esaslara göre bir cephe kuracak ve emir komuta birliğini sağlayacaktı ${ }^{42}$. 16 Kasım'da Denizli'ye gelen Albay Refet Bey, Heyet-i Milliye üyeleri ile görüşmüş ${ }^{43}$, buradan Albay Şefik Aker ile birlikte Nazilli'ye geçmiştir. Nazilli'ye gelen Refet Bey'i, Demirci Mehmet Efe, kalabalık bir zeybek topluluğu ile birlikte istasyonda karşılamıştır ${ }^{44}$.

Refet Bey' in bölgeye gönderildiğini Konya'da bulunan 12. Kolordu Kumandanı Fahrettin Bey'e haber veren M. Kemal, Fahrettin Bey'den Kurmay Binbaşı Nâzım Bey'inde bölgeye gönderilmesini istemiş, bunun 168.

${ }^{37}$ Zeki Sarıhan, Kurtuluş Savaşı Günlüğü, c.II., Ankara 1982,s.,164;Dayı, a.g.e. s.,

${ }^{38}$ Baykal, a.g.e. s., 22.

${ }^{39}$ Nutuk, s, 136.

${ }^{40}$ Baykal, a.g.e. s., 31., Akşin, a.g.e., II.,s., 77.

${ }^{41}$ Nutuk, s., 195.

${ }^{42}$ Mehmet Özdemir, "Mustafa Kemal Paşa'nın Emrinde Samsun'dan Sakarya'ya: Refet Paşa" Yeni Türkiye, c.15., Ankara 2002.s., 970.

${ }^{43}$ M. Akif Tütenk, Milli Mücadele'de Denizli, Ahenk, İzmir 1949,s,35.

${ }^{44}$ Gökbel, a.g.e. s.,389.; Aker, a.g.e., III.s., 9 
üzerine Nâzım Bey, 12. K.K. tarafından, Nazilli'ye Refet Bey'in yanına gönderilmiştir ${ }^{45}$.

\section{Refet Bey'in Bölgedeki Faaliyetleri ve Demirci Mehmet Efe:}

Heyet-i Temsiliye tarafından Aydın Kuvâ-yı Milliyesi'nin sevk ve idaresini almak amaciyla bölgeye gelen Refet Bey, Albay Şefik Aker'in emrinde olan askeri kanadın Kuvâ-yı Milliye ve Demirci Mehmet Efe üzerinde hiçbir tesirinin kalmadığını görmüştür ${ }^{46}$.

Bölgeye gelir gelmez, Demirci Mehmet Efe'den kumandayı almaya çalışmasının doğru olmadığı kanâatine varan Refet Bey, doğrudan kumandayı alma yerine, Demirci Mehmet Efe'yi kendisine yaklaştırmaya ve bu vesile ile Heyet-i Temsiliye ile olan münasebetlerini düzenlemeye karar verdi.

Refet Bey, Demirci Mehmet Efe ile Salihli Cephesi'nin kumandasını elinde bulunduran Çerkes Ethem Bey'i ziyaret etti. Demirci Mehmet Efe ile Refet Bey'in yapmış olduğu bu ziyareti Bezmi Nusret Kaygusuz şöyle anlatmaktadır: "...Ömer Lütfi Beyle beraber misafirleri karşılamak için kasabadan harice çıtık. Dombay kapı mevkiinde tevakkuf ettik. Ve daha uzaklara Mülâzım Tahsin Bey'i gönderdik. Tahsin Bey, seri bir yürüyüşle yanımıza döndü. Misafirlerin gelmekte oldukların müjdeledi. Ve Refet Bey'in "sakın bana fazla iltifat gösterilmesin. Bütün hürmetler Efeye yaptlsın" dediğini de ilave etti. Tavsiyesine harfiyen riayet ettik. Efe hazretlerini birinci plana aldik. Kendisine beyaz atının şahane yürüyüşünden bile bahseyledik. Efe yüzü mütecaviz seçme süvarisi ile etrafa heybet ve azamet saçarak Tevfik Bey'in konağına gitti. Refet ve Ömer Lütfi Beylerle ben eski püskü bir arabaya binerek firka karargahina gittik. ${ }^{47,}$

Refet Bey'in "sakın bana fazla iltifat gösterilmesin. Bütün hürmetler Efeye yapılsin" sözlerinden, Demirci Mehmet Efe'yi gücendirmek istemediği veya Efe'nin ön planda tutulmasının cephenin menfaatleri açısından daha faydalı olacağı kanaatine vardığını göstermektedir.

Demirci Mehmet Efe, bir iki gün kaldıktan sonra Refet Bey ile birlikte Nazilli'ye geri döndü. Bundan sonra Refet Bey, bölgedeki Kuvâ-yı Milliye'nin ve cephelerin durumu hakkında bilgi edinmek amacıyla Balıkesir'e geçmiştir. Refet Bey'in bu gezisi uzunca bir süre ve cephe

\footnotetext{
${ }^{45}$ Fahrettin Altay, On Yıl Savaş ve Sonrası, Ünsal yay., İstanbul 1970, s., 202.

${ }^{46}$ Gökbel, a.g.e. s, 389

${ }^{47}$ Bezmi Nusret Kaygusuz, Demirci Mehmet Efe'yi "yağız çehreli, ince bıyıklı, orta boylu, zaifce, çizmeli...Bir Türk köylü delikanlısı tipinde" şeklinde tanıtır ve Çerkes Ethem için hissettiği "haşyet ve ihtirazı" Demirci Mehmet Efe'de duymadığını, Efe'nin kendisine yabancı ve vahşi görünmediğini söyler. Bezmi Nusret Kaygusuz, Bir Roman Gibi, İzmir 2002, s.,188; Îlhan Tekeli- Selim İlkin, Ege'de Sivil Direnişten Kurtuluş Savaşı'na Geçerken Uşak Heyet-i Merkeziyesi ve Ibrahim (Tahtakılıç) Bey, TTK., Ankara 1989.s.,296
} 
bölgesinin dışında da devam etti. Refet Bey'in bu gezisi sırasında Heyet-i Temsiliye ile olan irtibatı kayboldu ${ }^{48}$.

Refet Bey, Nazilli'den ayrılırken Demirci Mehmet Efe'ye yapacağı seyâhat konusunda her hangi bir malûmât vermemiş olacak ki, Demirci Mehmet Efe, 12. K.K.Fahrettin Bey'e göndermiş olduğu telgrafta Refet Bey' in nerede olduğunu sormuş, Fahrettin Bey bu soruya vermiş olduğu cevapta, Refet Bey'in nerede olduğunu bilmediğini, sorduğunu fakat henüz cevap alamadığını belirtmiştir ${ }^{49}$.

Refet Bey'in bölgeden ayrıldığı bu sıralarda, Nazilli'ye, daha önce kendi kolordusuna bağlanan 57. Fırkayı teftiş etmek ve cepheyi yakından görmek amacıyla 12. K.K. Fahrettin Bey gelmiştir. Fahrettin Bey, hatıralarında bu seyâhati sırasında Demirci Mehmet Efe'nin kendisine takındığı tavır ile ilgili olarak şunları söylemektedir. " Demirci Mehmet Efe bana karşı hürmetkâr görünmekle beraber kendisini müstakil bir kumandan olarak görüp, Mustafa Kemal'den başkasını amir olarak tanımaz bir tavır takınıyor, bana misafir muamelesi yaptyordu $u^{50}$."

Fahrettin Bey'e, bu seyâhati sırasında, daha önce Refet Bey'in yanına göndermiş olduğu Nâzım Bey, cephe ile ilgili memnuniyetsizliğini dile getirmiştir. Nâzım Bey, "Refet Bey'in de bir şey yapamayacağını anlayarak bölgeden ayrıldığını" söyleyerek, Fahrettin Bey'den kendisinin başka bir yere görevlendirilmesini istemiştir ${ }^{51}$. Fahrettin Bey'e bölgeden alınması teklifini götürenler arasında 57. Fırka K. Şefik Aker de vardır. Aker, "Fahrettin Bey, bölgeye geldikten sonra, askeri hâkimiyetin temini için düzeltme işinin henüz mevsimsiz olduğunu anladığını" ifade ettikten sonra, Fahrettin Bey'den önce şîfâhen, avdetlerinden sonra da bir telgrafla, görevinin değiştirilmesini istediğini, ancak bu teklifinin 12. K.K. tarafından kabul edilmediğini belirtmiştir ${ }^{52}$.

Fahrettin Paşa, Konya'ya döndükten sonra 2 Aralık tarihinde Harbiye Nezâreti'ne göndermiş olduğu bir telgrafta, cepheden avdet ettiği gün Fırka Kumandanı Şefik Aker ile Demirci Mehmet Efe'nin muharebe sahasına gittiklerini belirtmiş, Demirci Mehmet Efe'nin çalışmalarının takdire şayan olduğunu sözlerine ilave etmiştir ${ }^{53}$.

Gerek Demirci Mehmet Efe'nin bölgeye gelen 12. K.K. Fahrettin Bey'e takınmış olduğu tavır ve gerekse Nâzım Bey ile Şefik Aker'in bölgeden alınmalarını isteyen teklifleri göz önüne alınırsa, Heyet-i Temsiliye'nin Refet Bey' e vermiş olduğu vazifenin zorluğu ortaya çıkar.

\footnotetext{
${ }^{48}$ Özdemir, a.g.m. s., 970

${ }^{49}$ ATESE,Ars.,KI:300 „D142:, Fh: 76

${ }^{50}$ Altay, a.g.e. s., 203.

${ }^{51}$ a.g.e.s., 203

${ }^{52}$ Aker, a.g.e., III.s., 11

${ }^{53}$ ATESE,Arş.,KI:39 ,D:63, Fh: 47
} 
Refet Bey, cephenin sevk ve idaresini Demirci Mehmet Efe'den almaması ve Heyet-i Temsiliye ile irtibat kurmadan bölgede bir geziye çıkması nedeniyle Mustafa Kemal tarafından eleştirilmiştir. Bu konularla ilgili olarak Mustafa Kemal Paşa, Nutuk'ta şunları dile getirmektedir: "Efendiler, Nazilli'ye giden Refet Paşa, Demirci Mehmet Efe'den komutayı almaya gerek ve bunda bir yarar görmemiş; kim bilir ve belki de komuta kendisine teslim edilmemiş. Demirci Mehmet Efe'nin emrinde kurmay gibi görev yapmayı daha yararl ve uygun bulmuş...Refet Paşa bunu bize bildirdi. Bölge şartlarını yakından görmüss bir zât kararını değiştirmek çok defa güçtür. Çünkü, gerçekten Refet Paşa'nın gördüğ̈̈ ve tercih ettiği gibi, Efe'nin komutasin devam ettirmekte ve ona yardımc olmakta yarar vardl yahut da Refet Paşa, o cephenin komutasinı her hangi bir sebeple ele alamıyordu. Her iki ihtimale göre de, mutlaka komutayı al diye emir vermek, anlamsız olurdu ${ }^{54}$. Mustafa Kemal Paşa, Refet Bey'in bölgede yapmış olduğu seyâhat ve İstanbul'a gitmesi ile ilgili olarak da "Efendiler, Refet Paşa'nın bu hafif hareketi, Aydın ve Salihli cephelerinde, düzenli bir ordunun teşkiline kadar, ciddi bir sevk ve idare kurulmamasina sebep oldu" demektedir ${ }^{55}$.

Mustafa Kemal Paşa'nın Refet Bey'in Demirci Mehmet Efe'den kumandayı almaması ile ilgili sarf etmiş olduğu ifadelere bakıldığı zaman, "tatlı-sert" bir tavır takındığı görülmektedir. Mustafa Kemal'in, Refet Bey'in Demirci Mehmet Efe'den kumandayı alamamasının nedenleri üzerine yürüttuiğü tahminler, gerçekten yerinde tespitlerdir. Refet Bey'in Demirci Mehmet Efe'den komutayı almaya gerek ve bunda bir yarar görmediği en kuvvetli ihtimaldir. Demirci Mehmet Efe'nin halk nazarındaki nüfuz ve itibarı, cephe ihtiyaçlarının karşılanmasındaki ve bölgedeki düzen ve âsâyişin sağlanmasındaki fonksiyonları göz önüne alındığı zaman, Refet Bey'in, Demirci Mehmet Efe'den kumandayı almaya kalkışması gerek cephedeki birlik ve beraberliğin sağlanması ve gerekse cephe ihtiyaçlarının sağlanması açısından bir çok sakıncaları beraberinde getirirdi. Kuvâ-yı Milliye içerisinde önemli bir mevkiye sahip olan zeybeklerin, Refet Bey'in itaati altına girmeleri bir hayli zordu. Üstelik, Demirci Mehmet Efe ile uyum içerisinde çalışan ve İstanbul Hükûmeti'ne ve Padişaha bağlılıklarında herhangi bir sorun olmayan Nazilli Heyet-i Merkeziyesi ile Refet Bey'in aynı uyumu yakalayabilmesi bir hayli güçtü. Eğer Refet Bey, kumandanın kendisine teslim edilmesini istemiş olsaydı, kuvvetli bir ihtimalle böyle bir teklifine ret cevabı alırdı. O halde Refet Bey için yapılacak en iyi hizmet "Demirci Mehmet Efe'nin emrinde onun kurmayt gibi" çalışmak olurdu.

Nitekim, Refet Bey, bir meclis görüşmesinde yapmış olduğu konuşmasında da bu anlamda sözler sarf etmiştir. "Demirci'nin yanına gittim. O zaman İstanbul'dan Demirci'nin yanına gelen bir zâbit Şarkın kuvvetleriyle( Temsil kuruluna bağlı kuvvetler kastediliyor) Demirci'nin

\footnotetext{
${ }_{55}^{54}$ Nutuk, s.195.

55 a.g.e. s.,196
} 
kuvvetlerini zıt bir hale koymak istiyordu. Çünkü o zaman Istanbul, Demirci'ye çalışınız diyordu. Onun için ben zorunlu olarak başka bir yol tuttum. Onlarda bu suretle iyi bir yol tuttular. Biz mefkuremiz (vatan kurtarmak) için her şeyi feda ettik. Ben kolordu komutanı iken geldim. Demirci'nin yanında tek başıma, elimde tek silah olduğu halde, her biri binlerce kan dökmüş zeybek içerisinde, onların yanına gittim ve orada Demirci'ye emir subaylığ y yaptım. Kolordu Komutanı olan ben, onun emir subaylığına tenezzül ettim. Orada hiçbir kuvvetim olmadı ̆̆ı halde manevî kuvvetimle başaracă̆ıma emin idim. Ve bütün manevî sorumluluğu üzerime aldım. Her hangi bir kimsenin burnu kanasa Refet Bey niçin engel olmuyorsun diyorlardl. O zaman Refet Bey'in nesi vardl. Sadece inanct $\operatorname{vardl} .^{56}$

Demirci Mehmet Efe'nin emrine giren Refet Bey'in ilk yaptığı işlerden birisi, Demirci Mehmet Efe'nin danışmanlığını yapan Nuri Bey'i bölgeden uzaklaştırmak ve Nuri Bey'in vazifesini üzerine almak oldu ${ }^{57}$. Nuri Bey'in görevinden uzaklaştırılmasında Karahisar'da çıkan İkaz gazetesinin 27 Kasım tarihli nüshasında, Demirci Mehmet Efe'ye açık mektup şeklinde, Nuri Bey'in "seyyiât"i hakkında bilgi veren yazı yazması da etkili olmuş olsa gerekir ${ }^{58}$.

Böylelikle Refet Bey, Demirci Mehmet Efe'nin yapacağı yazışmaları daha yakından takip etme imkanını elde etmiş oluyordu.

Refet Bey' in Demirci Mehmet Efe'nin karargahında yapmış olduğu bir başka değişiklik ise, Harekât-1 Harbiye Reisi olan Tâhir Bey'i, Demirci Mehmet Efe'nin askeri danışmanlığından alması ve 29 Aralık'tan itibaren, cephedeki Kuvâ-yı Milliyeyi Şefik Aker'in emrine, cephe gerisi âsâyiş ve hizmetlerini ise Demirci Mehmet Efe'ye vermesidir. ${ }^{59}$

Refet Bey, bu faaliyetlerinin sonucunda, bölgedeki dizginleri elinden kaçırmış olan Şefik Aker'i Demirci Mehmet Efe'ye yaklaştırmıştır. Daha önceleri Kuvâ-yı Milliye'nin orduyla olan ilişkisini belli etmemeye çalışan ve bu nedenle Demirci Mehmet Efe'ye gönüllü olarak yetkiyi devreden Aker, Refet Bey'in bölgeye gelmesiyle birlikte bu düşüncesini bir tarafa bırakarak, Demirci Mehmet Efe'ye daha yakın olmaya çalışmıştır.

${ }^{56}$ TBMM Gizli Celse Zabitları, c.2, s.885; Özdemir, a.g.m. s., 971

${ }^{57}$ Aker, bu konu ile ilgili olarak şöyle der: "O zamanlar bir kolordu kumandanlığı mevkiine haiz olduğu halde bir efenin katibi veya vekili olması, Refet Bey için bir küçülme gibi görünür. Fakat bizim gibi Nazilli'deki vaziyetin iç yüzünü ve muhitin şartlarını yakinen bilenler nazarında, izzeti nefisten fedakarlık ederek muvakkat bir zaman için bu küçülmeyi kabul eden mertebesi büyük bir devlet adamının şu hareketi; İstiklâl Harbi'nin muvaffakiyeti ve vatanın istihlası uğurunda ihtiyar edilmiş bir fedakarlık ve bir faziletti." Aker, a.g.e., III.s., 22 .

${ }^{58}$ İkaz gazetesi'nin bu tarihli nüshası bulunmadığı için bu yazıyı görebilme imkanımız olmadı. Bu yazının içeriği konusunda Burdur Askerlik Şubesi Başkanı İsmail Hakkı Bey, 12.K.K. Fahrettin Bey'i bilgilendirmiştir. ATESE, Arş.,KI:380,D:48, Fh: 48

59 Özdemir, a.g.m, s.,971; Sıtkı Aydınel, Güneybatı Anadolu'da Kuvâ-yı Milliye Harekâtı, KB.,Ankara 2002,s, 383 
Refet Bey, Mart 1920 yılının sonuna kadar kaldığı Demirci Mehmet Efe'nin karargahında çok önemli vazifeler görmüş, bir taraftan Demirci Mehmet Efe ile Heyet-i Temsiliye'ye arasındaki ilişkileri düzenlemeye çalışırken diğer taraftan bölgedeki kuvvetlere belli bir düzen vermeye çalışmıştır. Refet Bey, 6 Şubat 1920 verdiği bir emirle, Büyük ve Küçük Menderes havzaları bölgesinde bulunan bütün nizâmi ve millî kuvvetleri Menderes Grubu adı altında yeni bir teşkilat içinde toplamıştır ${ }^{60}$.

\section{A. Demirci Mehmet Efe'nin Hükûmet İşlerine Müdâhalesi}

Demirci Mehmet Efe'nin faaliyet gösterdiği bölgelerde Kuvâ-yı Milliye'nin işlerini zorlaştıran mülkî memurları görevlerinden aldığını ya da Kuvâ-y1 Milliye'ye hizmet etmelerinden dolayı İstanbul tarafından görevinden alınan ve yeni tayin edilen mülkî amirleri bölgeye kabul etmediği görülmüştür. Demirci Mehmet Efe'nin bu türden faaliyetleri arasında olan ve bu nedenden ötürü Ali Rıza Paşa Hükümeti ile Heyet-i Temsiliye arasında bir takım yazışmalara neden olan iki önemli mülkî âmir vardır. Bunlardan birincisi Menteşe Mutasarrıfı Hilmi Bey, diğeri ise Antalya Mutasarrıfı Cemâl Bey'dir.

Muğla Mutasarrıfı olan Serficeli Hilmi Bey, Demirci Mehmet Efe'nin Sivas'a gönderdiği üç kişilik heyet içerisinde yer alan şahıslardandır.

Hilmi Bey'in Muğla'daki görevini bırakarak Nazilli'ye gelmesi ve uzun bir süre Demirci Mehmet Efe'nin yanında kalması İstanbul Hükûmeti tarafından görevine son verilmesine neden olmuştur. İstanbul Hükûmeti'nin Mutasarrıf Hilmi Bey'i azlederek, yerine Ethem Bey'i göndermesini gazetelerden öğrenen Demirci Mehmet Efe, bu olaydan son derece müteessir olmuş, Dahiliye Nezareti'ne göndermiş olduğu bir telgrafname ile bu tepkisini dile getirmiştir ${ }^{61}$

Hilmi Bey'in görevinden azline tepki olarak Nazilli'den gönderilen bir diğer telgrafname ise, II. Nazilli Kongresi'ne Muğla Delegesi olarak katılan Menteşe Kuvâ-yı Milliye Reisi Mehmet Râgıp Bey'e aittir. Ragıp Bey, "Hükûmet-i sabıkanın cümle siyasetinden biri de amal-i millîye ile teşrik-i mesai eden nâmuslu ve himmetli memurları memuriyetlerinden azletmek idi" şeklindeki sözleriyle tepkisini göstermiştir ${ }^{62}$.

Görüldüğü gibi gerek Demirci Mehmet Efe, gerekse Ragıp Bey, Hilmi Bey'in azlini tepkiyle karşılamışlar ve her ikisi de bu durumundan Damat Ferit Hükûmeti'ni sorumlu tutmuşlardır.

Dâhilîye Nazırı Damat Mehmet Şerif Bey, Harbiye Nazırı Cemâl Paşa'ya bu iki telgraftan bahsederek, Mutasarrıf Hilmi Bey'in yapılan tahkikat sonucunda "hilaf-ı kanun bazı ahvâl ve muamelattan" dolayı "taht-1 muhakeme"ye alındığını ve yerine başka birinin tayin olunmasının

\footnotetext{
${ }^{60}$ Aker, a.g.e. III.s. 26.

${ }^{61}$ ATESE,Arş.,KI:61 ,D:18-3, Fh: (18-24)

${ }^{62}$ ATESE,Arş.,KI:61 „D:18-2, Fh: (18-24)
} 
kararlaştırıldığını hatırlatmıştır. Kuvâ-yı Milliye kumandanının salâhiyeti dışında "umur-1 hükûmete" müdâhalesinin ve bu konularda birtakım tekliflerde bulunmasının hiçbir şekilde kabul edilemeyeceğini ifade eden $\mathrm{M}$. Şerif Bey, Kuvâ-yı Milliye kumandanlarının hükûmet meselelerine müdâhale etmemelerinin temin edilmesini Harbiye Nazırı Cemâl Paşa'dan istemiştir ${ }^{63}$.

Dâhilîye Nezâreti'nin bu müracaâtı üzerine Harbiye Nazırı Cemâl Paşa, 3 Kasım tarihinde Konya'da bulunan 12.K.K.Fahrettin Bey'e göndermiş olduğu telgrafnamesinde Demirci Mehmet Efe'nin ve Râgıp Bey'in Hilmi Bey hakkında Dâhilîye Nezâreti'ne göndermiş oldukları telgraflardan ve isteklerinden bahsettikten sonra, Kuvâ-yı Milliye rüesa ve kumandanlarının ileri sürdükleri sebeplerin geçerliliği olmadığını, bu gibi taleplerde bulunmalarının ise hükûmet işlerine müdâhale anlamına geleceğini ifade etmiştir. Cemâl Paşa bu gibi müdâhaleye cevaz verildiği takdirde memleketin anarşiye düşeceğini, bu nedenle Kuvâ-yı Milliye rüesa ve kumandanlarının hükûmet işlerine müdâhale anlamına gelecek bu türden işlere kalkışmamaları konusunda icap ettiği şekilde tenvir edilmesini istemiştir $^{64}$.

Fahrettin Bey, Cemâl Paşa'nın bu telgrafına vermiş olduğu 3 Kasım tarihli cevabında, icap edenlerin memurinin azledilmesi, görevlerinden alınması vb. konularda tenvir edileceğini belirtmiş; Mutasarrıf Hilmi Bey'in yanında iki zat ile birlikte Sivas'a gitmek üzere 5 Kasım'da Konya'dan geçtiğini haber vermiştir ${ }^{65}$.

Hilmi Bey'in azledildikten sonra Demirci Mehmet Efe tarafindan Sivas'a gönderildiğini daha önce ifade etmiştik. Hilmi Bey, Sivas'a vardıktan sonra Heyet-i Temsiliye'nin toplantılarına katılmıştır.

22 Kasım tarihli Heyet-i Temsiliye toplantısında, Menteşe Heyet-i Milliye Reisi Hilmi Bey'in, Sivas'ta bulunan Mutasarrıf Hilmi Bey'in azledildiğine yönelik telgrafı okundu ${ }^{66}$. Bunun üzerine Heyet-i Temsiliye Reisi Mustafa Kemal Paşa, Demirci Mehmet Efe'nin kendilerine murahhas olarak gönderdikleri Hilmi Bey hakkında bir şey yapmayacaklarını, ahaliden ve birçok yerden de "adem-i tebdili" hakkında telgraflar geldiğini ifade etmiştir.

Heyet-i Temsiliye'nin Hilmi Bey hakkında hiçbir şey yapmayacağ yönündeki bu kararı ve birtakım memurinin değiştirilmesine ya da görevlerinden alınması yönündeki taleplerinden sonra, Harbiye Nâzırı Cemâl Paşa, 24 Kasım'da Mustafa Kemal'e göndermiş olduğu telgrafında "devletin umuru dâhilîye ve siyasiyesi katiyen iştirak kabul etmez" diyerek, hükûmetçe tayin olunan bazı memurların görev yapacakları mahallere

\footnotetext{
${ }^{63}$ ATESE,Arş.,KI:61 ,D:18-4, Fh: (18-24); B.O.A., DH-KMS, DN:53-3, VN:67

${ }^{64}$ ATESE,Arş.,KI:61 ,D:18-5, Fh: (18-24)

${ }^{65}$ ATESE,Arş.,KI:309 ,D:196, Fh: 80

${ }^{66}$ Uluğ İgdemir, Heyet-i Temsiliye Tutanakları, TTK.,Ankara 1969,s., 87
} 
gidememelerinden bahisle; Menteşe Mutasarrıfı gibi kanunen "taht-1 muhakeme" ye alınması lâzım gelenlerin, memuriyetlerinde kalmasında ısrar edilmesinden hatta murahhas sıfatı ile Sivas'a gönderilmesin duyduğu rahatsızlığı belirtir ${ }^{67}$.

Cemâl Paşa'nın bu telgraftan sonra, Heyet-i Temsiliye'nin 26 Kasım tarihli toplantısında Cemâl Bey'in sözünü ettiği meseleler görüşülür ${ }^{68}$.Mustafa Kemal Paşa, bu toplantıda Cemâl Paşa'nın Hilmi Bey'in taht-1 muhakemeye alınması isteğine karşılık olarak, bunu gerektiren durum hakkında malûmâtları olmadığını ifade etmiştir. Üyelerden Haydar Bey ise, Hilmi Bey’i kendilerinin çağırmadığını, Demirci Mehmet Efe'nin kendisinin gönderdiğini söylemiştir.

Haydar Bey'den sonra bu konuda söz alan Mustafa Kemal Paşa, Hilmi Bey hakkında hiçbir malûmâtlarının olmadığını, Kuvâ-yı Milliye'nin gönderdiği bir murahhası "gayr-i malum ve gayr-i muayyen" sebeplerden dolayı reddetmelerinin doğru olmayacağını ifade etmiştir. Reis Paşa, Hilmi Bey' in taht-1 muhakemeye alınması için hükûmeti bundan men edecek bir kuvvetin olmadığını da sözlerine ilave etmiştir.

26 Kasım tarihli bu toplantıdaki görüşmelerden sonra, Cemâl Paşa'nın 24 Kasım'daki telgrafına cevaben muhtelif konulardaki Heyet-i Temsiliye'nin görüşlerini bildiren bir telgrafı Mustafa Kemal, Harbiye Nazırı Cemâl Paşa'ya göndermiştir ${ }^{69}$. Mustafa Kemal, dört maddeden oluşan telgrafının üçüncü maddesinde, Demirci Mehmet Efe tarafından Sivas'a gönderilmiş olup avdet eyleyen, Hilmi Bey'in mahkumiyeti ve memuriyetinin kendilerince meçhul olduğunu yinelemiştir. Ayrıca, Damat Ferit Hükûmeti'nin acziyeti ve ihâneti yüzünden kendi 1rz ve namuslarını korumak zorunda kalan; bizzat "makam-1 akdes-i hilafete sadık ve vahdet-i milliyeye kaviyyen merbut olan" fedakar insanlar tarafından gönderilen bir murahhasa, kendilerince bilinmeyen bir sebepten dolayı bir şey yapılamayacağının aşikar olduğunu ifade etmiştir. Mustafa Kemal sözlerine, Hilmi Bey'in "taht-1 muhakemeye" alınması icap ediyorsa, hükûmetin icraât ve hareketinde serbest olduğuna vurgu yaparak son vermiştir.

Sivas ile İstanbul arasında yaşanan ve "sağırlar diyalogu"nu andıran bu gelişmelerden sonra, İstanbul hükûmeti Hilmi Bey'in peşini bırakmamıştır. Özellikle Dâhilîye Nazırı Mehmet Şerif Bey'in tutumu bu konuda etkili olmuştur. Kuvâ-yı Milliye taraftarlığıyla bilinen Harbiye Nazırı Cemâl Paşa'nın kulak ardı ettiği çoğu meseleler Dâhilîye Nazırı M. Şerif Paşa tarafından amansız bir takibe uğratılmış, bu konuda Harbiye Nezâreti'nin de kapısı aşındırılmaya çalışılmıştır. Cemâl Paşa, Dâhilîye Nazırı Mehmet Şerif

\footnotetext{
${ }^{67}$ Nutuk, s.200: Belge (194)

${ }^{68}$ İğdemir, a.g.e. s., 108

${ }^{69}$ Nutuk, s.,200.Belge (195)
} 
Bey’e, Hilmi Bey'in elindeki şifre miftahının alınması ile ilgili olarak, kendisine müracaât edilmesinin nedenini sorma ihtiyacı hissetmiştir ${ }^{70}$.

Dâhilîye Nezâreti'nin Hilmi Bey'in elindeki şifrenin alınmasına yönelik vilâyetler nezdindeki yazışmaları sürüp gitmiştir ${ }^{71}$.

Antalya Mutasarrıfı olan Cemâl Bey, Mustafa Kemal Paşa'nın millî teşkilata zarar veren davranışlar içerisinde bulunması nedeniyle İstanbul Hükûmeti'ne şikâyetçi olduğu memurlardan biridir ${ }^{72}$.

Cemâl Bey, 22 Ekim tarihinde Demirci Mehmet Efe, tarafından bir telgrafla, cephe ihtiyacı vesâir hususları görüşmek üzere Nazilli'ye çağrılmıştır. Cemâl Bey, Demirci Mehmet Efe'nin bu davetine, livânın siyasi vaziyeti ve seçim hazırlıkları nedeniyle icap edecek durumda olmadığını ifade ederek, davet karşısında nasıl bir tavır takınması gerektiğini Dâhilîye Nezâreti'nde sormuștur. Dâhilîye Nezâreti aynı gün vermiş olduğu cevapta, hali hazırdaki ahvâl nedeniyle görevlerinden ayrılmalarının doğru olmayacağını Kuvâ-yı Millîye Kumandanı'na ona göre cevap yazılmasını istemiştir $^{73}$.

Demirci Mehmet Efe ile Heyet-i Temsiliye arasında Cemâl Bey konusunda bir fikir birliği olsa gerekir ki, Demirci Mehmet Efe'nin Cemâl Bey'i Antalya'ya çağırmasından bir gün sonra yapılan Heyet-i Millîye'nin toplantısında, "Konya Valisi Cemâl Bey'in adamı olan Antalya mutasarrıfının yerine münasibi tayin edilmediği takdirde Demirci Mehmet Efe tarafından tevkif edileceği Harbiye Nazırı Cemâl Paşa'ya" bildirildi denilmektedir. Yine aynı toplantıda, Antalya Mutasarrıfı'nın birkaç gün zarfında hükûmet tarafından değiştirilmemesi halinde, Demirci Mehmet Efe'ye, kararı tatbik etmesi cevaben bildirilmiştir ${ }^{74}$.

Cemâl Bey'in hükûmet tarafından değiștirilmemesi durumunda, Demirci Mehmet Efe'ye hareket serbestliği tanınacağı, Heyet-i Temsiliye'nin 25 Ekim tarihli toplantısında yeniden dile getirilmiştir ${ }^{75}$.

Dâhilîye Nezâreti'nin uygun bulmamasına rağmen, Demirci Mehmet Efe'nin ısrarla çağırması sonucunda Cemâl Bey, Nazilli'ye gitmek zorunda kalmıştır.

Demirci Mehmet Efe'nin devlet işlerine müdâhale etme anlamına gelebilecek bu tavır ve davranışlarının yanında, Mustafa Kemal Paşa'nın da

${ }^{70}$ B.O.A., DH-KMS, DN:57-2, VN:39; Sivas'taki harekete yakınlığ Paşa ile Dâhilîye N. M. Şerif Bey' in arasının iyi olmadığı özellikle Konya Valisi Cemâl Bey'in tutuklanması vb. konularda her iki nazır arasında sert tartışmaların yaşandığı bilinmektedir. Akșin, a.g.e., II.s.,177. Dâhilîye N. M. Serif Bey' in bir takım icraatlarından, Atatürk de Nutuk'ta rahatsızlığını belirtmiştir. Nutuk, s.,156,196,197

71 B.O.A., DH-KMS, DN:57-2/5, VN:39; B.O.A., DH-KMS, DN:57-2/1 VN:39; B.O.A., DH-KMS, DN:57-2/10, VN:39

${ }^{72}$ Akşin, a.g.e. II.s.,146.

${ }^{73}$ B.O.A., DH-KMS, DN:53-3, VN:56

${ }^{74}$ Baykal, a.g.e. s., 31

${ }^{75}$ a.g.e. s., 33 
bazı memurların değiştirilmesine yönelik taleplerinin olması Harbiye Nazırı Cemâl Paşa'yı kızdırmıştır. Cemâl Paşa, 2 Kasım'da görevine gitmesine engel olunan Ziya Paşa ile ilgili olarak Mustafa Kemal Paşa'ya bir telgraf çekmiştir ${ }^{76}$.

Mustafa Kemal, 3 Kasım'da Cemâl Paşa'ya göndermiş olduğu cevap telgrafında, hükûmet ile millî teşkilat arasında samimi bir uzlaşmaya ve gerçek bir görüş birliğine vardıklarını belirttikten sonra, kendilerinden daha önce bir istirhamları olduğunu, "meşru bir gayeye yönelen millî teşkilatın zarar görmemesi için, bütün yüksek dereceli memurların bu görüşe göre seçilmesi ve karşı olanların değiştirilmesi"ni istediklerini hatırlatmıştır. Mustafa Kemal, ayrıca, Antalya Mutasarrıfı hakkında ne yapıldığını bilmediklerini Cemâl Paşa'ya duyurmuştur ${ }^{77}$.

Cemâl Paşa, Mustafa Kemal'in bu telgrafına vermiş olduğu 5 Kasım tarihli telgrafında, muhtelif konulardan bahsettikten sonra, taşralarda bazı kimseler tarafından, millî teşkilat adına hükûmet işlerine karışılmakta olduğunun, birbirini kovalayan bilgi ve haberlerden anlaşıldığından, bu karışmaların biran önce ve süratle önlenmesini istemiştir ${ }^{78}$. Cemâl Paşa'nın bu telgrafında sözünü ettiği "bazı kimseler" in önde gelen isimlerinden birisi Demirci Mehmet Efe'dir.

Mustafa Kemal, Cemâl Paşa'ya aynı gün vermiş olduğu cevapta, millî teşkilat adına, hükûmet işlerine nerede ve kimin tarafından karışılmışsa derhal bildirilmesini, ona göre gereken işlemlerin yapılacağını ifade etmiş, telgrafın son cümlesini Damat Şerif Bey'i kastederek şu şekilde bitirmiştir. " Ancak, Dâhilîye Nazırı Paşa Hazretleri'nin şüphe uyandırabilecek tarzdaki davranışlarına yüksek dikkatlerinizi çekmeyi gerekli görürü̈ ${ }^{79}$. . Anlaşılacağ gibi Mustafa Kemal, Dâhilîye'nin birtakım icraatlarından duyduğu rahatsızlığını Cemâl Paşa'ya îma etmiştir.

Cemâl Paşa, 8 Kasım'da Heyet-i Temsiliye Reisi'ne gönderdiği telgrafında, daha önce göndermiş olduğu telgrafındaki bu son cümlelerden maksadın ne olduğunun anlaşılmadığını, burasının acilen açıklanarak bildirilmesini istemiştir ${ }^{80}$.

Mustafa Kemal, Cemâl Paşa'nın bu kısa telgrafına, Dâhilîye Nezâreti'nin şüphe uyandıran tavır ve davranışlarını bildiren uzun bir cevap yazmıştır $^{81}$.Mustafa Kemal Paşa, bu cevabında, Antalya Mutasarrıfı Cemâl Bey ile ilgili olarak, "Konya Valisi vatan hâini Cemâl Bey'in adamı olan Antalya Mutasarrıfı, arka arkaya yaptığımız müracaâtlara ve halkın feryatlarına karşıllk olarak, hâlâ yerinde oturuyor" demiştir.

\footnotetext{
${ }^{76}$ Nutuk, s.192.

77 a.g.e. s, 192.

${ }^{78}$ A.g.e. s., 193

${ }^{79}$ A.g.e. s., 194

${ }^{80}$ A.g.e. s., 196

${ }^{81}$ A.g.e. s., 197
} 
Cemâl Paşa, 24 Kasım'da Sivas'a göndermiş olduğu “devletin umuru dâhilîye ve siyasiyesi katiyen iştirak kabul etmez" diye başlayan telgrafında, Demirci Mehmet Efe'nin Antalya Mutasarrıfı'nı Nazilli'ye azimete mecbur bırakmasından ve Aydın Vilâyeti'nden Hariciye ve Dâhilîye Nezâretlerine çekilecek şifre telgrafnamelerin telgrafhanece çekilmesine izin vermemesinden bahis açarak, isim kullanmaksızın Demirci Mehmet Efe'nin yapmış olduğu bu faaliyetlerin hükûmet işlerine müdâhale etmekten başka bir mana taşımayacağını ifade etmiş, bu tür hareketlerin önüne geçilmesini Mustafa Kemal'den istemiştir ${ }^{82}$.

Mustafa Kemal Paşa, Harbiye Nazırı'na cevaben 27 Kasım'da göndermiş olduğu telgrafında, hükûmet işlerine müdâhale edilmediğini ancak Damat Ferit Hükûmeti zamanında millî teşkilata zarar vermeye çalışan birtakım memurların, görevlerinden alınmaması ya da başka bir yere verilmesi nevînden hareketlerin, Damat Ferit zihniyetinin halen yaşatılmaya çalışıldığ hissini verdiğini ve bu durumdan Heyet-i Temsiliye'nin müşkül bir duruma düştüğünü ifade etmiştir. Bundan sonra sözü Antalya Mutasarrıfı Cemâl Bey'e getiren Mustafa Kemal Paşa, Kuvâ-yı Milliye aleyhtarlığıyla bilinen Antalya Mutasarrıfı'nın daha önceki müracaâtlarına rağmen halen makamında oturduğunu hatırlatarak, Cemâl Bey' in "melaneti” yüzünden İtalyanların, Antalya'da "Banko di Roma" şubesini kurarak ${ }^{83}$, ahaliye tohumluk dağıtmaya başladığını, mahalli hükûmetin lakaytlığı yüzünden bunun önüne geçilemediğini, halkın elindeki topraklarının, yirmi seneliğine kiralama bahanesiyle İtalyanlar tarafından işgal edilmeye ve Trablusgarp'ta olduğu gibi halkın elinden topraklarının alınmaya çalışıldığını Cemâl Paşa'ya anlatmıştır. Bu ifadelerinden sonra sözü, Demirci Mehmet Efe'nin Mutasarrıfı Nazilli'ye çağırması olayına getiren Mustafa Kemal Paşa, bu konu ile ilgili olarak şunları ifade etmiştir: "Tabii bu hal böyle devam ederse Antalya Mutasarrıfi'nı, hayat ve mematı için düşmanla pençeleşmekte bulunan Aydın Kuvâ-yl Millîyesi pek haklı olarak Nazilli'ye celbeder ve buna Heyet-i Temsiliye' ce de artık itiraz imkanı kalmaz"

Mustafa Kemal Paşa'nın gerek Cemâl Bey ve gerekse Hilmi Bey meselelerinde hükûmete karşı Demirci Mehmet Efe'nin faaliyetlerinin haklılığını savunan ya da onu destekleyen bir tavır takındığı dikkatlerden kaçmamaktadır.

Demirci Mehmet Efe'nin Kuvâ-yı Milliye taraftarı olan Hilmi Bey'in azlinde ve Cemâl Bey'in Antalya'daki faaliyetleri sonucunda vermiş olduğu tepkileri ayrıca Aydın'dan Dâhilîye ve Hariciye'ye telgraf gönderilmesini yasaklaması gibi faaliyetleri Heyet-i Temsiliye üyelerinin de dikkatini çekmiştir. Henüz tam olarak Heyet-i Temsiliye'nin Demirci Mehmet Efe üzerinde müessir olamadığı bu günlerde, Heyet-i Temsiliye üyeleri Demirci

\footnotetext{
${ }^{82}$ A.g.e., s.200: Belge (194)

${ }^{83}$ Mustafa Kemal Paşa'ya İtalyanların bölgede bu türden faaliyetlerde bulunduklarını Demirci Mehmet Efe haber vermiştir. İ̆demir. a.g.e.s., 109
} 
Mehmet Efe ile ilgili düşüncelerini, Heyet-i Temsiliye'nin 26 Kasım tarihli toplantısında dile getirmişlerdir. ${ }^{84}$

Demirci Mehmet Efe'nin bu şekildeki bağımsız hareket etmesinden Heyet-i Temsiliye rahatsız olmuş olacak ki Ali Fuat Paşa, o sıralarda Aydın cephesi ile yakından ilgilenen 12.K.K. Fahrettin Bey'e 29 Kasım'da göndermiş olduğu telgrafında, Demirci Mehmet Efe'nin göndermiş olduğu heyet üyeleri ile yapmış oldukları müzakereler sonucunda, Demirci Mehmet Efe'nin kendi kendine hareket etmeyip, Refet Bey'in emri altında hareket edeceğinin kararlaştırıldığını ve heyet üyelerinin bu konuda Demirci Mehmet Efe'ye bir telgraf gönderdiğini bildirmiștir. Ayrıca Ali Fuat Paşa, heyet üyelerinden, Nazilli'ye döndükten sonra Demirci Mehmet Efe'yi bu konuda yönlendireceklerine dair söz aldıklarını da sözlerine ilave etmiştir ${ }^{85}$.

Ali Fuat Paşa, her ne kadar bu şekilde isteklerde bulunmuş olsa da, Refet Bey'in Demirci Mehmet Efe üzerinde etkili olması o an için mümkün değildir. Çünkü bu sıralarda Refet Bey, Nazilli’de bile değildir ${ }^{86}$.

Hükûmetin Demirci Mehmet Efe üzerinde yapmış olduğu çaba ve gayretler sonucunda Antalya Mutasarrıfı Cemâl Bey, Nazilli'den kurtarılarak 8 Aralık'ta görevinin başına dönmüştür. Cemâl Bey'in Antalya'ya geldiği Fahrettin Bey tarafından Cemâl Paşa'ya bildirilmiştir ${ }^{87}$. Cemal Bey'in görevinin başına dönmesinden iki gün önce Demirci Mehmet Efe, Mustafa Kemal Paşa'dan Nazilli Kongresi kararları doğrultusunda Antalya'nın da Heyet-i Merkeziye'ye bir üye göndermesini istemiş ve bunun Sivas Kongresi

${ }^{84}$ Heyet-i Temsiliye'nin Kuvâ-yı Milliye'nin hükûmet işlerine müdâhale etmesini görüştüğü bu toplantıda söz alan Rauf Bey "En buhranll safha Aydın'da oluyor. Biz de bunu söylemek istemiyoruz ki, kuvvetleri Demirci Mehmet Efe yapıyor. Ve bunun üzerinde bizim hiçbir kuvve-i teyidiyemiz yoktur. Aramızı bozmaktır. Sonra da o bizi kabul etmez" demiştir. Rauf Bey'in "Biz de bunu söylemek istemiyoruz ki, kuvvetleri Demirci Mehmet Efe yapıyor" sözünden bölgedeki kuvvetlerin basında Demirci Mehmet Efe'nin yerine kendilerince tanınan bir başkasının olmasını istediği sezinleniyor. Bu sıralarda Refet Bey'in de bölgeye kumandayı almak amacıyla gönderilmesine rağmen, İstanbul'a kadar uzanacak olan bir geziye çıkmış olması ve Heyet-i Temsiliye ile irtibatını kaybetmiş olması dikkate alınmalıdır.

Rauf Bey'den sonra Mustafa Kemal Paşa söz alarak "Demirci Mehmet Efe yakın zamana kadar kimseyi tanımıyordu. Fuat Paşa ile temas neticesi bize müracaât etti. Bunun da sebebi orada Selahattin Bey adam olsaydl; bir Demirci Mehmet Efe çıkmazdı. Bunda Cemâl Paşa'nın da kabahatleri vardır. Bu şimdi hiç olmazsa daha fena yapmıyor. Cemâl Paşa bunları bildiği halde yine böyle yapıyor" şeklinde konuşmuștur. Mustafa Kemal Pașa'nın bu sözlerinden Demirci Mehmet Efe'nin daha önce Ali Fuat Paşa ile temasa geçmek istediği anlaşılıyor. Mustafa Kemal Paşa, bölgede Demirci Mehmet Efe'nin sevk ve idareyi ele almasında ve ön plana çıkmasında 12 . K.K. olan ve Temmuz ayı'nın bașlarında istifa ederek İstanbul'a giden Selahattin Bey'i kabahatli bulduğu gibi " $b u$ şimdi hiç olmazsa daha fena yapmıyor" sözleriyle de Demirci Mehmet Efe'nin faaliyetlerini destekler bir tavır takınmıştır.

Ali Fuat Paşa ise, "Bu gün Harbiye Nezâreti de, Heyet-i Temsiliye de Demirci Mehmet Efe ile temasa gelmek istemiştir. Çünkü bir kuvvettir. Fiiliyatla iş gösteriyor. Herkes bunu elde etmek istiyor" diyerek Demirci Mehmet Efe'nin Aydın bölgesi'ndeki nüfuz ve kuvvetini ifade etmeye calısmıstır.Ĭğdemir,a.g.e.s.,123,

${ }^{85}$ ATESE,Arş.,KI:300,D:122-13, Fh: 56(1:13)

${ }^{86}$ Ali Fuat'ın bu telgrafını çektiği sıralarda Refet Bey'in bölgede olmadığını Miralay Kâzım Bey'in anlatımlarından anlıyoruz. Kazıp Özalp, Milli Mücadele, C.I, TTK., Ankara 1998, s.,75

$$
{ }_{87} \text { Aynı.; B.O.A., DH-KMS, DN:53-4, VN:10. }
$$


kararlarına da hizmet edeceğini belirtmiștir ${ }^{88}$. Demirci Mehmet Efe'nin bu isteği üzerine Heyet-i Temsiliye Reisi Mustafa Kemal, Antalya Müdafaa-i Hukuk Cemiyeti Başkanlığı'na bir şifre göndererek, “Teşkilatın doğal olarak Sivas Kongresi'ne göre düzenlenip genişletileceğini ancak Nazilli'nin harp cephesi olması dolayısıyla Nazilli Kongresi'nde kararlaştırıldı ̆̆ı gibi Antalya'dan Nazilli Heyet-i Merkeziyesi'ne bir delege gönderilmesinin gerekli ve zaruri" olduğunu bildirmiştir ${ }^{89}$.

Görüldüğü gibi Demirci Mehmet Efe, Aydın, Menteşe ve Havalisi Kuvâ-yı Milliye Kumandanı olarak, bölgesinde Kuvâ-yı Milliye taraftarı olan Hilmi Bey gibi devlet adamlarının haksız bir şekilde görevlerinden alınmasına tepki göstermiş ya da Cemâl Bey gibi Kuvâ-yı Milliye aleyhinde faaliyetlerde bulunan, cephe ihtiyaçlarına ilgi göstermeyen devlet görevlilerini Nazilli'ye çağırarak onların Kuvâ-yı Milliye hakkındaki ön yargılarını izâle etmeye, Kuvâ-yı Milliye aleyhindeki faaliyetlerine engel olmaya çalışmıştır. Demirci Mehmet Efe'nin bu türden faaliyetlerde bulunurken Heyet-i Temsiliye'den hiçbir şekilde emir almadan hareket ettiği ancak olaylarla ilgili olarak Heyet-i Temsiliye'yi bilgilendirmeye çalıştığı gözden kaçmamaktadır.

Demirci Mehmet Efe'nin bu tarzdaki yaklaşımlarının yanında Heyet-i Temsiliye de Kuvâ-yı Milliye aleyhtarlığı ile bilinen kişilerin yola getirilmesinde Demirci Mehmet Efe'den yararlanma yoluna gitmiştir. Bir örnek vermek gerekirse Eskişehir bölgesinde Kuvâ-yı Milliye'ye aleyhtarlıklarıyla bilinen Topal Necip ve Seyitgazili Taip Ahmet Efendi adlı şahıslar bu tutumlarından dolayı Mutasarrıf Fatin Bey tarafından Heyet-i Temsiliye'ye şikâyet edilmiş, Heyet-i Temsiliye bu şahısların bölgeden uzaklaştırılması gerektiğini Demirci Mehmet Efe'ye haber vermiştir ${ }^{90}$. Demirci Mehmet Efe'nin bu konuda her hangi bir teşebbüste bulunup bulunmadığı bilinmemektedir.

\section{B. Demirci Mehmet Efe ile Heyet-i Temsiliye Arasında, Aydın Cephesi ile Ilgili Olarak Yapulan Yazışmalar}

Yunanlılar, Ödemiş bölgesinde Milne Hattı'nın kendilerine verdiğ imkandan faydalanmak isteyerek, 21 Kasım'da Kaymakçı üzerinden saldırıya geçmişlerdir. Yunanlıların bu taarruzu sırasında meşhur zeybeklerden Gökçen Efe şehit düşmüştür ${ }^{91}$. Yunanlıların Kasım ayının sonlarına doğru başlayan bu saldırılarından sonra Aydın Kuvâ-yı Milliyesi'nin silah ve cephane ihtiyacını karşılayabilmek amacıyla Demirci Mehmet Efe ve Heyet-i Temsiliye arasında bir takım yazışmalar olmuştur. Cephenin silah ve cephane ihtiyacının karşılanmasında 12.K.K. Fahrettin Paşa, Demirci Mehmet Efe ile Sivas arasında köprü vazifesini üstlenmiştir.

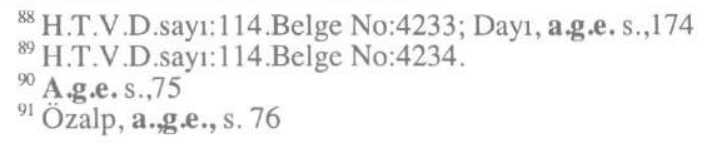


Yunanlılar ile Kuvâ-yı Milliye arasında başlayan çarpışmalarla ilgili olarak Demirci Mehmet Efe tarafından Konya'da bulunan 12.K.K. ve Sivas'a muhtelif zamanlarda bilgi verilmiştir. Ödemiş ve Salihli kesimlerinde yapılan Yunan taarruzları sebebiyle Demirci Mehmet Efe'nin, Mustafa Kemal Paşa'ya gönderdiği şu telgraf, o tarihlerdeki cephe durumunu göstermesi bakımından önemlidir:

"Yunanlılar, General Milne notasında gösterilen hattı çok üstün kuvvetlerle işgale başladılar. Ödemiş taraflarında ü̧̧ günden beri kanlı muharebeler oluyor. Hâin Ferit Paşa kabinesi zamanında hiçbir yerden yardım alamadık. Bir aydan beri her tarafa silah ve cephane için aralıksız. başvurulduğu halde sadece pek az miktar Konya'dan geldi. Bu günde Burdur'dan yüz sandlk gönderiliyor. Savaş bu şekilde devam edecek olursa mevcut cephane ile düşmana nihayet 10 gün mukavemet gösterilebilir. Bir hafta içinde 15.000 bin mücâhidi cepheye getirmek kolaydır. Bunlar silah ve cephanesizlik yüzünden getirilemiyor. Bazl yerlerden kuvvetli yardımlar alındıysa da, durum aleyhimize döndü̆̆̈̈ takdirde yapılacak yardımın hiçbir değer hükmü kalmayacaktır. Allah korusun, bu cephe bir felakete uğrarsa her tarafta büyük değişiklikler meydana gelecek ve memleket karmakarışık olacaktır. Aydın ve Ödemiş kesimlerinin cephane bitinceye kadar direneceklerine eminim. Salihli kesimi çok zayıftır. Üstelik Yunanlılar, dünden beri oraya taarruz ettikleri için bizden kuvvet ve yardım istiyorlar. Bir tek er bile gönderilmesine bu sirada imkan yoktur. Salihli kesimi hemen takviye edilmez ve düşman durdurulmazsa, bizim de durumumuz pek güçleşecektir. Hâlen süregelmekte olan Ödemiş Muharebeleri'nde çok kahraman ve cesur erlerimiz şehit oldular. Bununla beraber kanımızın son damlasını akıtmak hususunda kararımız kesindir. Kütahya ve Afyonkarahisar'daki cephanelikleri basarak bol cephane temini mümkündür. Fakat İngilizlerle her hangi bir çatışmaya tutuşmak istemiyoruz. Gereğinin bildirilmesi ricâ olunur. . $^{92}$

Demirci Mehmet Efe'nin “15.000 bin mücahidi cepheye getirmek kolaydır" ifadesinden, onun cepheye asker celbi meselesinde kendisinin nüfuz ve otoritesine ne derece güvendiğini ortaya koymaktadır. Ayrıca, silah ve cephane konusunda 1 srarcı bir tutum takınması ve kendisinin başında bulunduğu cephenin çökmesi durumunda, olabileceklere dikkat çekmesi gerçekten önemlidir. Demirci Mehmet Efe'nin Kütahya ve Afyonkarahisar'da cephanelik olduğunu bildirmesi ve bu konuda İngilizlerle

${ }^{92}$ TiH, 2/2,s.,162; Aydınel, a.g.e. s., 331'de Demirci Mehmet Efe'nin bu telgraft çekmesinde, Nazilli'ye giden Refet Bey ve Fahrettin Paşa tarafından cepheye gönderilen Nâzım Bey'in etkilerinin olabileceğini, Demirci Mehmet Efe'nin bu tarihten önce Mustafa Kemal ile irtibata geçmediğini belirtir. Halbuki,- daha önce de ifade ettiğimiz gibi- Demirci Mehmet Efe, 15 Ekim'de Mustafa Kemal'e bir telgraf göndererek Sivas Kongresi kararlarını tanıdıklarını belirtmiş, cephe için silah ve cephane talebinde bulunmuştur. Üç kișiden oluşan bir de heyet göndermiștir. Dahası Demirci Mehmet Efe ile Mustafa Kemal arasında bundan önce irtibat olduğu Heyet-i Temsiliye'nin kararlarında geçen ifadelerden rahatlıkla anlaşılabilir. Baykal, a.g.e. s.,31-33-42 
her hangi bir çatışmaya girmekten kaçındıklarını ifade etmesi de dikkate şayandır ${ }^{93}$.

Demirci Mehmet Efe'nin bu telgrafından sonra, Mustafa Kemal Paşa, 25 Kasım'da 12. K.K. Fahrettin Paşa'dan, Yunanlıların önemli bir şekilde taarruza başlamaları hasebiyle mücahitlerin silah, cephane ve icabında makineli tüfek ve topçu kıtaatı ile takviye edilmesini istedi ${ }^{94}$. Aynı gün Efe'nin adına Müşavir Nuri Bey tarafından Fahrettin Paşa'ya gönderilen telgrafta, Yunanlılarla olan çarpışmaların devam ettiği, Efe'nin üç gündür cephede olduğu bildiriliyor; Burdur ve Afyonkarahisar'daki cephanenin gönderilmesi isteniyordu ${ }^{95}$.

$\mathrm{Bu}$ tarihten iki gün sonra Mustafa Kemal Paşa, 12.K.K.Fahrettin Paşa'ya göndermiş olduğu telgrafında, Demirci Mehmet Efe'nin göndermiş olduğu raporlardan Yunanlıların taarruza başladıklarının anlaşıldığını ifade ettikten sonra, Yunan kuvvetlerinin hiçbir mahalde muvaffak olmaması gerektiğini, mahallerde yapılacak mukabîl taarruzlarla Yunan kuvvetlerinin büsbütün perişan edilmesinin 'vaziyet-i hazıra' üzerinde pek faydalı olacağını belirtmiş, bunun için gerekli olan cephane, silah ve îcâbında makineli tüfek ve topçu gibi kitaatla da muâvenet edilmesi isteğini tekrarlamıştır $^{96}$. Bu arada Demirci Mehmet Efe'nin silah ve cephane konusundaki talepleri Harbiye Nezâreti'ne iletilmiş olacak ki, Kuvâ-yı

${ }^{93}$ Demirci Mehmet Efe'nin İngilizlerin Nezâreti altında bulunan cephaneliklere dikkat çekmesi sonucunda bu mesele Heyet-i Temsiliye üyeleri tarafından tartışılmıştır. Heyet-i Temsiliye üyeleri bu konu ile ilgili olarak şu görüşleri ifade etmişlerdir.

Reis Paşa - Biz 12. Kolordu'ya ricâ etmiştik..

Şemsi Bey- Evet Efendim. Biz bir miktar göndermiştik. Fakat yine istiyorlar. Afyonkarahisar'da cephane var fakat İngilizlerin taht-1 Nezâretinde.

Rauf ve Rüstem Beyler-Bassinlar Efendim.

Reis Paşa-Fakat Kolordunun fikrini bilmiyoruz.

Şemsi Bey-------Fransızlarında bir taburu vardır.

Fuat Paşa.-----Biz aynen 12. kolorduya yazarız. Tabii emrini verir, muâvenetini yapar.

Reis Paşa__ Muâvenetini yaptığı kadar yapmış. Şimdi Afyonkarahisarı'ndaki cephane ne olacak ? cephede bir taraftan muharebe oluyor. Kuvâ-yı Milliye'nin cephanesi yok. Geride var. Fakat İngilizler muhafaza ediyor. Bunu Mehmet Efe Yapamaz mı?

Rauf Bey_ Ben denizce bundan başka çare yok. Mahzur da yok. Mademki karar vermişler, millet kuvvettir. Cephane lâzımdır.

Fuat Paşa__ Eğer cephane kalmamışsa Afyonkarahisarı'ndaki büyük debboyu vermeli. Halbuki silah ve cephaneleri satıyorlar. Hakikaten cephane ve tüfekleri yok mudur.? Lütfi Bey'in fikri de böyle. Demirci Mehmet Efe'ye buna mani olması için yazıldı, mani olamadı. Sözümüzü dinlemiyor. Cephane ve tüfekleri tamamiyla vardır. Demirci Mehmet Efe'nin sözünü dinlemedense, fırkaya aynen yazılır. İcap ederse oradaki depoyu millî bir baskın tarzında kaldırmak mümkündür. Bunu Lütfi Bey yapabilir. Esasen Burdur taraflarındaki cephaneleri de alıyor. Demirci Mehmet Efe, birçok hayvanat gönderip oradan yükleterek külli miktarda oradan kolaylıkla celbediyor. Bendenize kalırsa, bu işi oraya havale edelim. 12 . Kolorduya ve Efe'ye de yazalım..

Rauf Bey__ Biraz da çalışıyoruz demeli;iltîfâtkâr yazalım.

Reis Paşa__ Fahrettin Bey'e de yazalım ki , eğer cephaneye lüzûm varsa onu millî olarak yapmalı

Fuat Paşa___ müsaade buyurularsa, o telgrafı ben denize veriniz. Toptan bir şey yazarım. Ora ahvaline vakıfım.. İğdemir, a.g.e., s.,108

${ }_{94}$ Baykal, a.g.e. s., 64

${ }^{95}$ ATESE,Arş.,KI:300, D:122, Fh: 56(1:13)

${ }^{96}$ ATESE,Arş.,KI:303, D:217, Fh: 78 
Milliye'nin her türlü ihtiyacının Harbiye Nezâreti tarafından karşılanacağı ve bu yönde kolordulara gereken emirlerin verildiği bilgisi, Heyet-i Temsiliye tarafından Demirci Mehmet Efe'ye bildirilmiştir. ${ }^{97}$

Demirci Mehmet Efe, 1 Aralık tarihinde Fahrettin Paşa'dan Burdur'daki 3 bin şarapnelin cephane ile birlikte gönderilmesini istemiştir. Ayrıca Denizli'den cepheye yardım gönderildiğini, Yenişehir'den gelecek silah için de Eğridir Heyet-i Milliyesi'ne gerekli emirlerin verildiğini de sözlerine ilave etmiştir ${ }^{98}$. Fahrettin Bey, Demirci Mehmet Efe'ye bunun ancak beș yüz tanesinin gönderilebileceğini, kalan kısmının ise diğer cephelere gönderileceğini bildirmiştii ${ }^{99}$.

2 Aralık tarihinde Mustafa Kemal Paşa, 12. Fırka kumandanlığına göndermiş olduğu bir telgrafında, Yunalıların bir haftadan beri Salihli, Aydın cephelerinde başlatmış oldukları taarruzdan ne gibi bir neticenin hasıl olduğunu ve Salihli cephesinin 23. Fırka tarafından daha fazla takviyesinin mümkünatını sorduktan sonra, Demirci Mehmet Efe'nin silah ve bilhassa cephane istediğini fakat muharebenin devam etmesi nedeniyle bu talebin derhal ifasının mümkün olamadığını bildiriyordu. Mustafa Kemal Paşa, cephane olarak elde İngilizlerin denetiminde olan Afyonkarahisar'daki cephanelik kalmış ise, bundan yararlanılması gerektiğini, cebren alınamadığı takdirde, cephane ve silahsızlık yüzünden Kuvâ-yı Milliye'nin başarısızlığa uğrayacağını; bunun ise düşmanın cesaretini artıracağını, Kuvâ-yı Milliye'nin kendilerine duyduğu itimadı kaybedeceğini Fahrettin Paşa'ya anlattıktan sonra, cepheye azâmî surette silah ve cephane yardımında bulunulmasını "pek samimi olan arkadaşlarımızdan intizar ederiz" demiştir ${ }^{100}$.

Mustafa Kemal Paşa, cephenin, silah ve cephane ihtiyacının karşılanmasının önemini bu şekilde Fahrettin Bey'e izah ettikten sonra, aynı gün Demirci Mehmet Efe'ye keyfiyeti bildiren bir telgraf göndermiştir ${ }^{101}$.

Aydın Kuvâ-yı Milliyesi'nin silah ve cephane ihtiyacının karşılanmasında Mustafa Kemal Paşa'nın büyük gayretler sarf ettiği bu yazışmalardan anlaşılmaktadır.

Aydın Kuvâ-yı Milliyesi'ne nerelerden silah ve cephane sağlanabileceği Harbiye Nazırı Cemâl Paşa'ya sorulmuş olacak ki, Cemâl Paşa, 12.K.K.'na göndermiş olduğu bir telgrafında "Kolordu Mintıkasındaki silah ve cephane depoları hakkındaki düşüncelerini ve icap eden hususları harbiye dairesi piyade şubesi Müdürü Binbaşı Cevat Bey'e izah ettiğini maruzâtın kabul olunmasını" istemiştir ${ }^{102}$. Bundan sonra $12 . K . K . '$ 'lı̆̆ına bağlı birlikler arasında silah ve cephane gönderilmesine ve topçu birliklerinin yerlerinin

\footnotetext{
${ }^{97}$ Baykal, a.g.e. s.,66

${ }_{98}^{8}$ ATESE,Arş.,KI:300, D:122, Fh: 56(1:13)

${ }^{99}$ Ayn1.

100 ATESE,Ars.,KI:304, D:135, Fh: 53

${ }^{101}$ Baykal, a.g.e. s.,68

${ }^{102}$ ATESE,Arş.,KI:300, D:122, Fh: 56(1:13)
} 
değiştirilmesine ilişkin uzun yazışmalar olmuştur ${ }^{103}$. Bu yazışmaların ve yer değiştirmelerin Aydın Kuvâ-yı Milliyesi'nin ihtiyaçları olan silah ve cephane yardımını sağlama amacına yönelik olduğu açıktır.

Bundan sonra Demirci Mehmet Efe, 7 Aralık tarihinde Fahrettin Bey'e Mustafa Kemal Paşa'nın, cephenin ihtiyaçlarının karşılanması ile ilgili olarak kendisine vermiş olduğu malûmâttan bahis ettikten sonra, bu güne kadar kendisine yapılan yardımlardan dolayı "müteşekkir" ve "mahsun" olduğunu, bu sebeple kendilerini "vatanın hakiki muhiplerinden" saydığını belirtmiştir. Demirci Mehmet Efe, cephenin ihtiyaçlarının karşılanmasında gösterdiği gayretlerden dolayı Fahrettin Bey’i bu şekilde taltif ettikten sonra Yunanlıların tekrar Ödemiş cephesinden taarruz edebileceklerini, Aydın'ın Gölcük ve Kavakbulan civarındaki muhaberelerden cepheyi zorlayacaklarının anlaşıldığını bildirmiştir. Demirci Mehmet Efe, cephenin silah ve cephaneye olan ihtiyacını şu şekilde ifade etmiștir. "Cephane ve tüfek ihtiyacr pek şedittir. Buraya lâakal 500-600 sandık cephane ile iki bin kadar tüfek yetiştirilmesi pek elzem ve zaruridir. Çünkü geçen ki Ödemiş Muharebesi yine pek çok cephane sarf ettirdi. Ve ihtiyat olmak üzere yeniden 50 sandık daha gönderdim. Umûmî bir harbe değil, mevzi ve devamlı bir muharebeye de başlanmıs olsa eldeki cephane ancak 3 gün idareye kâfi gelir.Bu sebeple tekrar himmet ve vataniyenize müracaât ediyorum. Soma ve Bergama cephelerinde şu dakikaya kadar harbin şiddetle devam ettiğine göre yakında buralara da ayn şekilde gideceği tabidir. Her halde bu husustaki muâvenetinde sürat-i ibraz buyrulmasını umum mücâhedat namına tekrar ehemmiyetle ricâ ve bu vesile ile de ihtiramat takdim ederim ${ }^{104}$."

Demirci Mehmet Efe'nin silah ve cephaneye ilişkin bu talepleri karşısında Fahrettin Paşa, zor durumda kalmış olsa gerekir ki, bir taraftan Burdur Ask.Şb. başında bulunan İsmail Hakkı Bey'den orada bulunan mühimmat deposunda bulunan cephanenin miktarını sorarken, diğer taraftan da 57.Fırka Kumandanı Şefik Aker'e "Aydın cephe kumandanı mütemâdiyen silah istiyor. Halbuki gönderecek silah kalmamıştır" diyerek, bulunduğu bölgeden cephane ve silah yardımı yapılamayacağını belirtmiştir ${ }^{105}$. Şefik Aker, Fahrettin Bey'e vermiş olduğu cevabında, Yunanlıların Menteșe ve Antalya sahillerinden yapabilecekleri muhtemel saldırılara dikkat çekmiş ve fırka taburlarında bulunan silahların elden çıkarılmaması gerektiğini ifade etmiştir. Ayrıca silah ihtiyacını temin edebilmek için halkın elinde bulunan silahlara müracaât edeceklerini de sözlerine ilave etmiştir ${ }^{106}$.

${ }^{103}$ Aynı.

${ }^{104}$ ATESE,Arş.,KI:300, D:123, Fh: 57

105 12.K.K. Fahrettin Paşa'nın Şefik Aker'e göndermiş olduğu bu telgrafında Demirci Mehmet Efe için "Aydın Cephe Kumandanı" tabirini kullanması, bölgedeki emir-komutanın Demirci Mehmet Efe'de olduğunu göstermesi açısından önemlidir. ATESE,Arş.,KI:300, D: 126-6, Fh: 60(1:5)

${ }^{106}$ ATESE,Arş.,KI:300, D:126-5, Fh: 60(1:5) 
Demirci Mehmet Efe, 15 Aralık'ta Mustafa Kemal Paşaya, "kanlı bir muharebeden sonra" Aydın gediğinin alındığını ve bu muharebe sırasında Yunanlıların büyük kayıplar verdiğini bildirmiştir ${ }^{107}$. Mustafa Kemal Paşa, 17 Aralık tarihinde, "Aydın ve Menteşe Umum Kumandanı Demirci Mehmet Efe" hitabıyla başlayan cevabında, Aydın gediğinin ele geçirilmesi ve Yunanlılara verilen zayiatın kendilerini sevindirdiğini bildirmiş, bu başarılarından dolayı Demirci Mehmet Efe'yi tebrik etmiştir ${ }^{108}$.

Demirci Mehmet Efe'nin, Yunanlılarla olan çarpışmalar hakkında Mustafa Kemal Paşa'ya vermiş olduğu raporlardan bir diğeri 16 Aralık tarihlidir. Demirci Mehmet Efe, bu raporunda 12-13 Aralık tarihinde Ödemiş cephesinde meydana gelen muharebeler hakkında Mustafa Kemal Paşa'ya tafsilatlı bilgi vermiştir ${ }^{109}$. Demirci Mehmet Efe, 19 Aralık tarihinde 12.K.K.'na göndermiş olduğu raporunda Yunanlıların Ödemiş cephesindeki faaliyetlerinden bahis ettikten sonra, Ödemiş cephesinde beş yüz kadar silahsız efradın bulunduğunu ve diğer cephelerde de aynı durumun söz konusu olduğunu beyan ile cephenin takviyesi için silah ve cephane yardımı yapılmasını istemiştir ${ }^{110}$.

Demirci Mehmet Efe'nin gerek Mustafa Kemal Paşa'ya gerekse 12.K.K.Fahrettin Bey'e göndermiş olduğu bu raporların altında "Umum Kumandan" mührünü kullandığı ve bölgeye gönderilen Refet Bey ile ilgili olarak her hangi bir ibarenin olmadığı görülür.

Demirci Mehmet Efe her ne kadar Heyet-i Temsiliye ile yazışmalarda bulunsa da tamamen Mustafa Kemal Paşa'nın direktifleri doğrultusunda hareket etmemiştir. Demirci Mehmet Efe'nin bu nedenle zaman zaman Mustafa Kemal Paşa tarafından uyarıldığı görülür.

Bir örnek vermek gerekirse; İngiltere ve Fransa'nın 14 Şubat'ta İstanbul'un Türklerde kalacağına dair kararı ile ilgili olarak, Demirci Mehmet Efe tarafından " Mücâhitlerimizin faaliyetlerinin bir sonucu olarak Yunanlıların çekileceği, ve Osmanlı hâkimiyetinin idâmesinin Londra Konferansı'nca kararlaştırıldığı" tarzında "Umum Müdâfaa-i Milliye Riyaseti"ne hitâben bir telgraf gönderilmiştir ${ }^{111}$. Demirci Mehmet Efe'nin bu telgrafı üzerine Mustafa Kemal Paşa, bölgeye "Nazilli Mevki Kumandanı Servet Bey" takma adıyla gönderilen Refet Bey'e bir telgraf göndermiştir. Mustafa Kemal Paşa, mezkûr telgrafında Demirci Mehmet Efe'nin İstanbul'un Türklerde kalacağına ve İzmir'in boşaltılacağına ilişkin tamimine atıfta bulunduktan sonra, "henüz takarrür etmeyen husûsâtın tamiminin bilahare sukût-ı hayale sebep olacağından teyit ve tevsik edilmeyen bu türlü malûmâtın itasinın menini" Refet Bey'den istemiştir ${ }^{112}$.

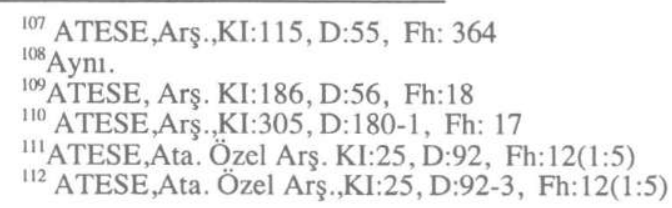


Mustafa Kemal Paşa'nın bu uyarısından sonra Menteşe Müdâfaa-i Hukuk Cemiyeti'nin başkanlığını yapan Ulya Cemâl ve Şefik Aker, Heyet-i Temsiliye'ye bir telgrafname göndererek, İtalyanların Antalya Mevki Kumandanı'nın Demirci Mehmet Efe tarafından etrafa yayılan bilgileri tekzip ettiğini bildirmiştir ${ }^{113}$. Mustafa Kemal Paşa, 25 Şubat tarihinde vermiş olduğu cevabında, bu tarz harekette bulunanların 21 Şubat tarihli bir telgrafname ile uyarıldığı konusunda Şefik Aker'i bilgilendirmiştir ${ }^{114}$.

Mustafa Kemal Paşa'nın bu uyarılarından sonra, Demirci Mehmet Efe, 25 Şubat tarihinde altında Refet Bey'in takma adının da yer aldığı bir telgrafnameyi Mustafa Kemal Paşa'ya göndermiştir ${ }^{115}$. Demirci Mehmet Efe, bu telgrafında Mustafa Kemal Paşa'ya yapmış olduğu uyarıdan dolayı teşekkür etmiş, karşılarındaki düşmanın hiç muâvenetinin kalmadığını ifade etmiştir. Demirci Mehmet Efe, telgrafını, "daima tebşî́râtınızı bekler, hürmetler,selamlar, takdim eylerim" diyerek tamamlar.

Demirci Mehmet Efe, 10.3.1920 tarihinde Mustafa Kemal Paşa’ya göndermiş olduğu bir başka telgrafında "fevkalâde ihtiyaca binâen" üç bin silah ve cephanenin on gün içinde Nazilli'ye gönderilmesini ister. Demirci Mehmet Efe, bu silah ve cephanenin cepheye ulaşması ile birlikte doğacak emniyet ve sükûn ortamından yararlanarak "Zât-1 Samileriyle" görüşmek üzere Ankara'ya geleceğini Mustafa Kemal Paşa'ya bildirmiştir.Mustafa Kemal Paşa, Demirci Mehmet Efe'nin kendisi ile görüşme isteğini “lüzûm görülen silah ihtiyacı temin edilecek. Bizzat konuşmamıza sizin meşguliyetinizin ehemmiyeti buna imkan vermez" şeklinde cevaplandırmıştır ${ }^{116}$.

Demirci Mehmet Efe'nin göndermiş olduğu bu telgrafın altında Refet Bey'in de ismi vardır. Öyle anlaşılıyor ki Demirci Mehmet Efe, Refet Bey' in cephede bulunmasından istifade ederek çevresindeki insanların kendisinden övgüyle söz ettikleri Mustafa Kemal Paşa ile yüz yüze görüşmek istemiştir.

Aydın Kuvâ-yı Milliyesi'nin Kumandanlığını deruhte eden Demirci Mehmet Efe, çok istemesine rağmen Mustafa Kemal Paşa ile yüz yüze görüşemeyecektir. Demirci Mehmet Efe'nin Mustafa Kemal Paşa ile olan ilişkileri T.B.M.M'nin açılmasından tenkiline kadar ki süreçte de devam etmiştir.

\section{SONUÇ}

Yunanlıların, İzmir'i işgali ile başlayan ve sonraki günlerde devam eden mezalimleri, Aydın Kuvâ-yı Milliyesi'ni ortaya çıkarmıştır. Vatanlarını düşman işgalinden kurtarmak amacında olan vatanperver insanlar, oluşturdukları cephe ve cephe gerisi teşkilatlanma ile kısa sürede

\footnotetext{
${ }^{113}$ ATESE,Ata. Özel Arș.KI:25, D:92-4, Fh:12(1:5)

114 ATESE,Ata. Özel Arş.,KI:25, D:92-5, Fh:12(1:5)

115 ATESE, Ata. Özel Ars.,KI:25, D:92-6, Fh:12(1:5)

${ }^{116}$ H.T.V.D.c.7,say1.12.(Haziran 1955)Vesika No:32
} 
Yunanlıların ilerleyişini yavaşlatan bir kuvvet olarak ortaya çıkmışlardır. Aydın Kuvâ-yı Milliyesi'nin bölgedeki teşkilatlanma faaliyetlerinde I.Nazilli Kongresi (7-8 Ağustos 1919) ile II. Nazilli Kongresi (23 Eylül 1919) arasında geçen zaman dilimi önemlidir. Bu tarihler arasında Aydın cephesi kendi içerisinde birtakım siyasi çalkantılar ve liderlik mücadeleleri ile uğraşmaktadır ve bu sürecin sonucunda bölgede "otoritesi" tartışmasız kabul edilen kişi eski bir zeybek ama şimdi Aydın Kuvâ-yı Milliye Kumandanı olan Demirci Mehmet Efe'dir.

$\mathrm{Bu}$ tarihler arasında, bölgede ortaya çıkan bu kuvveti kendi siyasetleri doğrultusunda yönlendirmeye çalışan iki grup ya da düşünce vardır: Bunlardan birincisi; Damat Ferit Hükümeti'nin siyasetini benimseyen ve cephede bu hesapla tavır ve telkinlerde bulunan insanlar, diğeri ise, Doğu'daki Mustafa Kemal'in başlattığ 1 "ulusalcı" harekete sempati besleyen ve bu yönde tavır sergileyenler.

Bu iki gruptan biricisi, bölgedeki bu kuvveti Damat Ferit'in iktidardan düşeceği tarihe kadar yanında tutmayı başarmıştır. Ancak bölgedeki bu grup hiçbir zaman, mücahitleri düşmana silahla karşı koyma düşüncelerinden vazgeçirememiștir. Başarabildikleri tek șey, Mustafa Kemal önderliğindeki hareket ile bu kuvvetin erken tarihlerde münasebet kurmalarını geciktirmek olmuştur.

Yunan işgalinin bölgedeki sonuçlarını gözleriyle gören Aydın Kuvâ-yı Milliyesi'nin önderlerinin, Damat Ferit'in siyasetini benimsemeleri mümkün değildi. Zaten bu insanlar hiçbir zaman Damat Ferit'in siyasetine ve şahsına karşı gönülden bağlanmamışlardır. Onların bağlılığı, hükümetten ayrı tuttukları "halife-padişaha"dır.

Nitekim, Damat Ferit'in iktidardan düşülmesinden hemen sonra Aydın Kuvâ-y1 Milliyesi gerek Sivas ile gerekse İstanbul ile irtibata geçme, destek alma yollarını aramıştır. İstanbul ile Sivas'ın uzlaşmacı siyaseti sayesinde Aydın Kuvâ-yı Milliyesi gerek İstanbul'dan gerekse Sivas'tan mümkün olduğunca lojistik olarak desteklenmiș, kimi zaman bağımsız olarak kimi zamanda bu iki otoriteye bağlı olarak "icra kuvveti" rolü oynamıștır. Zaman içerisinde bu kuvvetin Heyet-i Temsiliye'ye olan bağlılığ 1 daha çok belirginleșmiștir. Bunda bölgeye gönderilen Refet Bey'in izlemiş olduğu akıllı ve kurnaz siyasetin etkisi olduğu gibi, Mustafa Kemal'in, hareketin başında bulunan Demirci Mehmet Efe'nin zeybeklik gururunu okşayan, cezbedici üslubunun da etkisi inkar edilemez. Demirci Mehmet Efe'nin Kuvâ-y1 Milliye döneminde 'mafevki' olarak gördüğü tek kumandan Mustafa Kemal Paşa'dır. Bu akıllı siyasetin ve bağlılığın bir sonucudur ki, daha sonraki dönemde Demirci Mehmet Efe ve onun emrindeki kuvvetler, Mustafa Kemal ve arkadaşlarını Çerkes Ethem ve Kuvâ-yı Seyyare kadar uğraştırmamıştır. 


\section{FAYDALANILAN KAYNAKLAR \\ 1-ARŞIV BELGELERİ}

Genel Kurmay Askeri Tarih ve Stratejik Daire Başkanlığı Arşivi(ATASE)

Başbakanlık Osmanlı Arşivi (BOA)

Ankara Üniversitesi Türk İnkılâp Tarihi Enstitüsü Arşivi (TİTE)

\section{2-KİTAPLAR}

Aker, M. Şefik, İstiklâl Harbi’nde 57. Tümen ve Aydın Millı̂ Cidali, Askeri Mecmua,c.I.,Istanbul 1937

Akşin, Sina, İstanbul Hükûmetleri ve Millî Mücadele, Türkiye İş Bankası yay.,II, İstanbul 1983.

Albayrak, Mustafa, Milli Mücadele Döneminde Batı Anadolu Kongreleri, AAM., Ankara 1998.

Altay, Fahrettin On Yıl Savaş ve Sonrası, Ünsal yay., İstanbul 1970.

Arıburnu, Kemal, Sivas Kongresi, A.A.M., Ankara 1997.

Atatürk, Mustafa Kemal, Nutuk, A.A.M. Ankara 2002.

Atatürk’ün Millî Dış Politikası ,I. K.B., Ankara 1992.

Aydınel, Sıtkı, Güneybatı Anadolu'da Kuvâ-yı Milliye Harekâtı, KB.,Ankara 2002.

Bayar, Celal, Ben de Yazdım, C.7, Baha Matbaası,İstanbul 1967.

Baykal, Bekir Sitkı, Heyet-i Temsiliye Kararları, TTK., Ankara 1974.

Cebesoy, Ali Fuat, Millî Mücadele Hatıraları, Temel yay, İstanbul 2000.

Çarıklı, Hacim Muhittin, Balıkesir ve Alaşehir Kongreleri ve Hacim Muhittin Çarıklı'nın Kuvayı Millîye Hatıraları(1919-1920), yay. Haz. Şerafettin .

Dayı, Esin, Nazilli Kongreleri, Atatürk Üniversitesi., Erzurum 1998.

Gökbel, Asaf Milli Mücadele’de Aydın, Coşkun Matbaası, Aydın 1964.

İğdemir, Uluğ, Heyet-i Temsiliye Tutanakları, TTK.,Ankara 1969.

Kaygusuz, Bezmi Nusret, Bir Roman Gibi, İzmir 2002.

Özalp, Kazım, Milli Mücadele,C.I, TTK., Ankara 1998.

Özkaya, Yücel, Milli Mücadele'de Ege ve Çevresi, Kültür Bakanlığı yay., Ankara 1994

Sarıhan, Zeki, Kurtuluş Savaşı Günlüğüu, c.II., Ankara 1982.

Tekeli,-İlhan İlkin, Selim, Ege'de Sivil Direnişten Kurtuluş Savaşı'na Geçerken Uşak Heyet-i Merkeziyesi ve İbrahim (Tahtakılıç)Bey, TTK.,Ankara 1989. 
Türk İstiklâl Harbi, c.II.,Kısım I, Genelkurmay Basımevi, Ankara 1999.

TBMM Gizli Celse Zabıtları, c.2

Türkeş, Ünal, Kurtuluş Savaşı'nda Muğla, İstanbul 1973..

Tütenk, M. Akif, Milli Mücadele'de Denizli, Ahenk, İzmir 1949.

\section{3-MAKALELER}

Mehmet Özdemir, “Mustafa Kemal Paşa'nın Emrinde Samsun'dan Sakarya'ya: Refet Paşa” Yeni Türkiye, c.15., Ankara 2002.

4-SÜRELİ YAYINLAR

Harp Tarihi Vesikaları Dergisi

Vakit Gazetesi

Demokrat İzmir Gazetesi 